\title{
On the symmetry of tsumcorite group minerals based on the new species rappoldite and zincgartrellite
}

\author{
H. Effenberger ${ }^{1, *}$, W. Krause ${ }^{2}$, H.-J. Bernhardt ${ }^{3}$ and M. Martin ${ }^{4}$ \\ ${ }^{1}$ Institut für Mineralogie und Kristallographie, Universität Wien, Althanstraße 14, A-1090 Vienna, Austria \\ ${ }^{2}$ Henriette-Lott-Weg 8, D-50354 Hürth, Germany \\ ${ }^{3}$ Ruhr-Universität Bochum, Institut für Mineralogie, Universitätsstraße 150, D-44780 Bochum, Germany \\ ${ }^{4}$ Heinrich-Zille-Weg 8, D-09599 Freiberg, Germany
}

\section{ABSTRACT}

Rappoldite, the Co-analogue of helmutwinklerite, and zincgartrellite, the Zn-dominant analogue of gartrellite, are two new members of the tsumcorite group. Both minerals are triclinic, their structures are closely related to the parent structure, i.e. the 'tsumcorite type' $(C 2 / m, Z=2)$. The lower symmetry is caused by two different crystal-chemical requirements. Order phenomena of the hydrogen bonds cause the 'helmutwinklerite type' $(P \overline{1}, Z=4)$, ordering of $\mathrm{Cu}^{2+}$ and $\mathrm{Fe}^{3+}$ is responsible for the 'gartrellite type' $(P \overline{1}, Z=1)$.

Rappoldite was found on samples from the Rappold mine near Schneeberg, Saxony, Germany. The new species forms red to red-brown prismatic and tabular crystals up to $1 \mathrm{~mm}$ long. $D_{\text {calc. }}=5.28 \mathrm{~g} / \mathrm{cm}^{3}$. $2 \mathrm{~V}_{\mathrm{z}}=85(5)^{\circ}, n_{\mathrm{x}}=1.85$ (calc.), $n_{\mathrm{y}}=1.87(2)$ and $n_{\mathrm{z}}=1.90(2)$; dispersion is distinct with $r>v$; orientation is $Y \sim \|[\overline{1} 20]$ and $X \sim \| c$. The empirical formula derived from electron microprobe analyses is $\left(\mathrm{Pb}_{1.01} \mathrm{Ca}_{0.01}\right)_{\Sigma 1.02}\left(\mathrm{Co}_{0.99} \mathrm{Ni}_{0.62} \mathrm{Zn}_{0.35} \mathrm{Fe}_{0.02}\right)_{\Sigma 1.98}\left[\left(\mathrm{AsO}_{4}\right)_{1.99}\left(\mathrm{SO}_{4}\right)_{0.01}\right]_{\Sigma 2.00}\left[(\mathrm{OH})_{0.02}\left(\mathrm{H}_{2} \mathrm{O}\right)_{1.98}\right]_{\Sigma 2.00}$ or $\mathrm{Pb}(\mathrm{Co}, \mathrm{Ni})_{2}\left(\mathrm{AsO}_{4}\right)_{2} \cdot 2 \mathrm{H}_{2} \mathrm{O}$. Single-crystal $\mathrm{X}$-ray studies showed average $\mathrm{C} 2 / \mathrm{m}$ symmetry. Weak superstructure reflections are responsible for triclinic symmetry and enlarged cell metrics (refined from powder data): $a=11.190(2) \AA, b=10.548(2) \AA, c=7.593(1) \AA, \alpha=100.38(1)^{\circ}, \beta=109.59(2)^{\circ}$, $\gamma=98.96(1)^{\circ}, V=807.6 \AA^{3}, Z=4$. The superstructure results from the hydrogen-bond scheme, but faint streaks indicate some disorder. All investigated rappoldite crystals are twinned by reflection on ( $2 \overline{3} 0$ ) which corresponds to the mirror plane of the average $C 2 / m$ cell. Helmutwinklerite is isotypic with rappoldite and probably also with pure thometzekite; sulphatian thometzekite is monoclinic.

Zincgartrellite forms green-yellow rosette-like aggregates on samples from the Tsumeb mine, Namibia. The $D_{\text {calc. }}=5.30 \mathrm{~g} / \mathrm{cm}^{3} .2 \mathrm{~V}_{\mathrm{x}}=87(5)^{\circ}, n_{\mathrm{x}}=1.91(2), n_{\mathrm{y}}=1.94$ (calc.) and $n_{\mathrm{z}}=1.97(2)$. Electron-microprobe analyses and Mössbauer data yielded the empirical formula $\left(\mathrm{Pb}_{0.97} \mathrm{Ca}_{0.04}\right)_{\Sigma 1.01}\left(\mathrm{Zn}_{0.91} \mathrm{Cu}_{0.51} \mathrm{Fe}_{0.59} \mathrm{Al}_{0.03}\right)_{\Sigma 2.04}\left[\left(\mathrm{AsO}_{4}\right)_{1.96}\left(\mathrm{SO}_{4}\right)_{0.01}\right]_{\Sigma 1.97}\left[(\mathrm{OH})_{0.81}\left(\mathrm{H}_{2} \mathrm{O}\right)_{1.31}\right]_{\Sigma 2.12}$ or $\mathrm{Pb}(\mathrm{Zn}, \mathrm{Fe}, \mathrm{Cu})_{2}\left(\mathrm{AsO}_{4}\right)_{2}\left(\mathrm{H}_{2} \mathrm{O}, \mathrm{OH}\right)_{2}$. The structural formula is $\mathrm{Pb}\left(\mathrm{Zn}_{x} \mathrm{Fe}_{1-x}\right)\left(\mathrm{Zn}_{x} \mathrm{Cu}_{1-x}\right)\left(\mathrm{AsO}_{4}\right)_{2}(\mathrm{OH})_{1-x}$ $\left(\mathrm{H}_{2} \mathrm{O}\right)_{1+x}$ with $0.4<x<0.8$. Gartrellite is defined by $x<0.4$. Helmutwinklerite has $x$ near to 1 and is defined by a cell with fourfold volume. Single-crystal X-ray studies of zincgartrellite proved space group $P \overline{\mathrm{I}}$ caused by ordering of $\mathrm{Fe}^{3+}$ and $\mathrm{Cu}$ at one atomic site. Cell parameters (refined from powder data): $a=5.550(1) \AA, b=5.620(1) \AA, c=7.621(1) \AA, \alpha=68.59(1), \beta=69.17(1), \gamma=69.51(1)^{\circ}$, $V=200.1 \AA^{3}, Z=1$.

Kerwords: tsumcorite group minerals, rappoldite, zincgartrellite, helmutwinklerite, gartrellite, thometzekite, crystal symmetry, crystal chemistry, crystal structure, infrared spectra.

\section{Introduction}

THE minerals of the tsumcorite group show a remarkable variety in their chemical composition and crystal symmetry. The general formula is

* E-mail: herta.silvia.effenberger@univie.ac.at $\operatorname{Me}(1) M e(2)_{2}\left(\mathrm{XO}_{4}\right)_{2}\left(\mathrm{OH}, \mathrm{H}_{2} \mathrm{O}\right)_{2}: M e(1)=\mathrm{Pb}, \mathrm{Ca}$, 


\section{H. EFFENBERGER ETAL.}

$\mathrm{Bi}, \mathrm{Na} ; \mathrm{Me}(2)=\mathrm{Fe}^{3+}, \mathrm{Co}, \mathrm{Ni}, \mathrm{Cu}, \mathrm{Zn}, \mathrm{Mn}^{3+}, \mathrm{Al} ; X$ $=\mathrm{P}, \mathrm{As}, \mathrm{V}, \mathrm{S}$ (Krause et al., 1998a,b, 1999a,b and references therein). However, the particular elements and their combinations occur with different frequency and show different crystalchemical effects. At least two different valences are possible for each of the cations $M e(1), M e(2)$ and $X$. Charge balance is achieved by a coupled exchange at these positions and by adapting the ratio $\mathrm{OH}: \mathrm{H}_{2} \mathrm{O}$. Most of the tsumcorite group minerals have space-group symmetry $\mathrm{C} 2 / \mathrm{m}$. Details of the structure type were discussed by Tillmanns and Gebert (1973). This parent structure of the whole mineral group is denoted 'tsumcorite type'. Two different phenomena are responsible for a symmetry reduction: (1) order between $\mathrm{Cu}$ and $\mathrm{Fe}$ requires two distinct $M e(2)$ sites ('gartrellite type'); and (2) two $\mathrm{H}_{2} \mathrm{O}$ molecules per formula unit (pfu) require a reorganization of the hydrogen bonding scheme ('helmutwinklerite type'). Both symmetry reductions result in triclinic unit cells, which differ in their cell volume. At the time of preparing the earlier papers (Krause et al., 1998a,b) the only triclinic members of the tsumcorite group were gartrellite, $\mathrm{Pb}(\mathrm{Cu}, \mathrm{Zn})(\mathrm{Fe}, \mathrm{Zn})\left(\mathrm{AsO}_{4}\right)_{2}\left(\mathrm{OH}, \mathrm{H}_{2} \mathrm{O}\right)_{2}$, phosphogartrellite, $\mathrm{PbCuFe}\left(\mathrm{PO}_{4}\right)_{2}\left(\mathrm{OH}, \mathrm{H}_{2} \mathrm{O}\right)_{2}$ and helmutwinklerite, $\mathrm{PbZn}_{2}\left(\mathrm{AsO}_{4}\right)_{2} \cdot 2 \mathrm{H}_{2} \mathrm{O}$. Due to insufficient data, the definition of a separate $\mathrm{Zn}$ dominant mineral between helmutwinklerite and gartrellite was impossible. The evidence for triclinic symmetry of helmutwinklerite was very poor; the larger unit cell was based on only a few extremely weak superstructure reflections.

In the meantime, the new mineral rappoldite, $\mathrm{Pb}(\mathrm{Co}, \mathrm{Ni})_{2}\left(\mathrm{AsO}_{4}\right)_{2} \cdot 2 \mathrm{H}_{2} \mathrm{O}$, was discovered, and it can be regarded as the $\mathrm{Co}$ analogue of helmutwinklerite. Additional analytical and structural data have now justified the definition of zincgartrellite, $\mathrm{Pb}(\mathrm{Zn}, \mathrm{Cu})(\mathrm{Zn}, \mathrm{Fe})\left(\mathrm{AsO}_{4}\right)_{2}$ $\left(\mathrm{OH}, \mathrm{H}_{2} \mathrm{O}\right)_{2}$, as an independent mineral. The investigations were mainly based on a new technology (CCD area detector for X-ray singlecrystal diffractometer): weak $\mathrm{X}$-ray spots and streaks which were not seen before could be detected. These results were essential for the discussion given in the present paper.

The name rappoldite is for the type locality, the Rappold mine near Schneeberg, Saxony, Germany. Type material is deposited in the collection of the Bergakademie Freiberg, Germany. Zincgartrellite has been found on samples from the Tsumeb mine, Namibia. The name was chosen to show the relationship to gartrellite. Type material is preserved in the collection of the Institut für Mineralogie, University of Bochum, Germany. Detailed data on zincgartrellite were reported previously (Krause et al., 1998a) under the name 'zincian gartrellite' (sample number \#081), which is identical to the type material described in this paper. Both the minerals and mineral names have been approved by the IMA Commission on New Minerals and Mineral Names (rappoldite: \#98015; zincgartrellite: \#98-014).

\section{Occurrence and physical data}

Rappoldite was found in 1991 on samples from the dumps of the Rappold mine (RappoldFundgrube), Schneeberg-Neustädtel, Saxony, Germany. Access to the dumps was only possible in the course of excavation works in that area from March to October 1991. The samples were originally believed to contain tsumcorite (Martin and Schlegel, 1992). Subsequent studies showed this material to be a new mineral, namely the $\mathrm{Co}$ analogue of helmutwinklerite. The type specimen is $\sim 10 \mathrm{~mm}$ in diameter. It consists of quartz overgrown with rappoldite crystals in small rosette-like crystal aggregates which are red in colour. Rappoldite forms idiomorphic crystals. They are prismatic or tabular, up to $1 \mathrm{~mm}$ in length and up to $0.3 \mathrm{~mm}$ in diameter. Red-brown aggregates of tabular crystals have also been found, which were shown to be intergrowths with small amounts of cobaltlotharmeyerite. Additional secondary minerals within the collected dump material are cobaltaustinite, scorodite, barium-pharmacosiderite, olivenite, conichalcite, erythrite, arseniosiderite, mimetite and beudantite. Accompanying ore minerals are native silver and bismuth, acanthite, galenite, pyrite and skutterudite.

Zincgartrellite was discovered on specimens from the Tsumeb mine, Namibia. The new mineral forms aggregates up to $0.5 \mathrm{~mm}$ which are composed of very small yellow-green tabular crystals $(<0.1 \mathrm{~mm})$. The poor development of the crystals and their intensive intergrowth prevented the complete determination of the physical and optical data. The investigated samples can be attributed to the mining period 1975-1980 and were purchased by G. Tremmel at that time in Namibia. In the type specimen, zincgartrellite is grown on massive chalcocite covering an area of $\sim 4 \mathrm{~cm}^{2}$. It is associated with wulfenite, duftite, $\beta$-duftite (intermediate between duftite and 


\section{SYMMETRY OF TSUMCORITE GROUP MINERALS}

conichalcite, Kharisun et al., 1998), cuproadamite, and olivenite.

The physical and optical data of rappoldite and zincgartrellite are given in Table 1 .

\section{Chemical composition}

Chemical analyses of rappoldite and zincgartrellite were carried out by means of electron microprobe measurements. The results are compiled in Table 2. No other elements with atomic numbers $>8$ were detected. The standards used were mimetite $(\mathrm{As}, \mathrm{Pb}), \mathrm{CuS}(\mathrm{Cu})$; andradite $(\mathrm{Fe}, \mathrm{Ca}), \mathrm{Bi}_{2} \mathrm{~S}_{3}(\mathrm{Bi}), \mathrm{AlPO}_{4}(\mathrm{Al}), \mathrm{SrSO}_{4}(\mathrm{~S}), \mathrm{ZnO}$ $(\mathrm{Zn}), \mathrm{NiO}(\mathrm{Ni})$; and $\mathrm{Co}$ metal $(\mathrm{Co})$. A direct determination of $\mathrm{H}_{2} \mathrm{O}$ was not possible due to the small amount of pure material available. The water contents were therefore recalculated from the ideal compositions. Only small amounts of $\mathrm{Ca}$ substituting for $\mathrm{Pb}$ at the $\mathrm{Me}(1)$ position and of $\mathrm{S}$ substituting for As at the $X$ position could be detected. Mössbauer investigations showed the $\mathrm{Fe}$ in zincgartrellite to be completely trivalent (cf. Krause et al., 1998a, sample \#081). Rappoldite and zincgartrellite are completely soluble in warm dilute hydrochloric acid.

Rappoldite contains only traces of trivalent cations at the $\operatorname{Me}(2)$ position and therefore has two $\mathrm{H}_{2} \mathrm{O}$ molecules pfu. The empirical formula based on 10 oxygen atoms is $\left(\mathrm{Pb}_{1.01} \mathrm{Ca}_{0.01}\right)_{\Sigma 1.02}$ $\left(\mathrm{Co}_{0.99} \mathrm{Ni}_{0.62} \mathrm{Zn}_{0.35} \mathrm{Fe}_{0.02}\right)_{\Sigma 1.98}\left[\left(\mathrm{AsO}_{4}\right)_{1.99}\right.$ $\left.\left(\mathrm{SO}_{4}\right)_{0.01}\right]_{\Sigma 2.00}\left[(\mathrm{OH})_{0.02}\left(\mathrm{H}_{2} \mathrm{O}\right)_{1.98}\right]_{\Sigma 2.00}$ or in a simpler form, $\mathrm{Pb}(\mathrm{Co}, \mathrm{Ni})_{2}\left(\mathrm{AsO}_{4}\right)_{2} \cdot 2 \mathrm{H}_{2} \mathrm{O}$.

The electron microprobe analyses of zincgartrellite indicate a distinct solid solution involving $\mathrm{Zn}, \mathrm{Cu}, \mathrm{Fe}$ and minor Al. The empirical formula based on 10 oxygen atoms is $\left(\mathrm{Pb}_{0.97} \mathrm{Ca}_{0.04}\right)_{\Sigma 1.01}$ $\left(\mathrm{Zn}_{0.91} \mathrm{Cu}_{0.51} \mathrm{Fe}_{0.59} \mathrm{Al}_{0.03}\right)_{\Sigma 2.04}\left[\left(\mathrm{AsO}_{4}\right)_{1.96}\right.$ $\left.\left(\mathrm{SO}_{4}\right)_{0.01}\right]_{\Sigma 1.97}\left[(\mathrm{OH})_{0.81}\left(\mathrm{H}_{2} \mathrm{O}\right)_{1.31}\right]_{\Sigma 2.12}$. This sample was used for optical investigations, $\mathrm{X}$-ray work (including single-crystal structural refinements), and Mössbauer studies (see Krause et al, 1998a). Further samples, not suitable for these investigations, showed even higher $\mathrm{Zn}$ contents up to $13 \mathrm{wt} \% \mathrm{ZnO}$ with the corresponding chemical formula of $\mathrm{Pb}_{1.03}\left(\mathrm{Zn}_{1.08} \mathrm{Cu}_{0.50} \mathrm{Fe}_{0.37} \mathrm{Al}_{0.03}\right)_{\Sigma 1.98}\left(\mathrm{AsO}_{4}\right)_{1.99}$ $\left[(\mathrm{OH})_{0.45}\left(\mathrm{H}_{2} \mathrm{O}\right)_{1.59}\right]_{\Sigma 2.04}$. The simplified formula of zincgartrellite is $\mathrm{Pb}(\mathrm{Zn}, \mathrm{Fe}, \mathrm{Cu})_{2}\left(\mathrm{AsO}_{4}\right)_{2}$ $\left(\mathrm{H}_{2} \mathrm{O}, \mathrm{OH}\right)_{2}$, the structural formula is $\mathrm{Pb}\left(\mathrm{Zn}_{x} \mathrm{Fe}_{1-x}^{3+}\right)\left(\mathrm{Zn}_{x} \mathrm{Cu}_{1-x}\right)\left(\mathrm{AsO}_{4}\right)_{2}(\mathrm{OH})_{1-x}$ $\left(\mathrm{H}_{2} \mathrm{O}\right)_{1+x}$. The definition field of zincgartrellite and gartrellite was estimated somewhat arbitrarily from the triclinic distortion of selected $h \mathrm{kl}$ pairs within the gartrellite-zincgartrellitehelmutwinklerite series. Accepting that the

TABLE 1. Physical and optical properties of rappoldite and zincgartrellite.

\begin{tabular}{lll}
\hline Property & \multicolumn{1}{c}{ Rappoldite* } & Zincgartrellite \\
\hline Habit & prismatic $\|[\overline{1} 20]$ & tabular on $\{111\}$ \\
Morphology & $\{210\},\{001\}$ & $\{111\}$ \\
Lustre & vitreous & vitreous \\
Diaphaneity & transparent & transparent to translucent \\
Colour & red to red-brown & green-yellow \\
Streak & light yellow brown & yellow \\
Fluorescence & none & none \\
Hardness (Mohs) & 4.5 & 4.5 \\
Tenacity & brittle & brittle \\
Fracture & conchoidal & not determined \\
Cleavage & none observed & none observed \\
Density & $5.28 \mathrm{~g} / \mathrm{cm}^{3}(\mathrm{calc})$. & $5.30 \mathrm{~g} / \mathrm{cm}^{3}$ (calc.) \\
Optical character & biaxial positive & biaxial negative \\
2V & $85(5)^{\circ}$ & $87(5)^{\circ}$ \\
Refractive indices & $1.85($ calc.), $1.87(2), 1.90(2)$ & $1.91(2), 1.94$ (calc.), $1.97(2)$ \\
Dispersion & $r>\nu$, distinct & not determined \\
Orientation & $Y \sim[\overline{1} 20], X \sim \| c$ & not determined \\
Pleochroism & none & weak, $X=Z$ pale yellow, $Y$ yellow \\
\end{tabular}

* The orientation is given with respect to the triclinic supercell 


\section{H. EFFENBERGER ETAL.}

TABLE 2. Microprobe analyses of rappoldite and zincgartrellite.

\begin{tabular}{lrccccc}
\hline Constituent & Mean $^{*}$ & $\begin{array}{c}\text { Rappoldite } \\
\text { Range }\end{array}$ & Calculated* & Mean $^{\$}$ & $\begin{array}{c}\text { Zincgartrellite } \\
\text { Range }\end{array}$ & Calculated $^{\dagger}$ \\
\hline $\mathrm{PbO}$ & 35.27 & $34.64-36.11$ & 34.82 & 33.49 & $31.89-35.83$ & 33.66 \\
$\mathrm{CaO}$ & 0.12 & $0.00-0.38$ & 0 & 0.35 & $0.08-0.64$ & 0.35 \\
$\mathrm{Bi}_{2} \mathrm{O}_{3}$ & 0.11 & $0.00-0.30$ & 0 & - & - & - \\
$\mathrm{Fe}_{2} \mathrm{O}_{3}$ & 0.28 & $0.09-0.86$ & 0 & 7.23 & $6.59-7.68$ & 7.28 \\
$\mathrm{Al}_{2} \mathrm{O}_{3}$ & $<0.05$ & - & - & 0.26 & $0.08-0.53$ & 0.24 \\
$\mathrm{CuO}$ & $<.05$ & - & - & 6.26 & $5.19-7.15$ & 6.25 \\
$\mathrm{ZnO}$ & 4.52 & $3.58-4.96$ & 4.44 & 11.40 & $10.51-12.21$ & 11.38 \\
$\mathrm{CoO}$ & 1.60 & $10.64-2.17$ & 11.69 & $<0.05$ & - & - \\
$\mathrm{NiO}$ & 7.31 & $6.59-8.34$ & 7.58 & $<0.05$ & - & - \\
$\mathrm{As}$ & 35.82 & $34.55-36.45$ & 35.85 & 34.72 & $32.78-36.58$ & 35.92 \\
$\mathrm{SO}_{3}$ & 0.11 & $0.02-0.19$ & 0 & 0.13 & $0.00-0.25$ & 0.13 \\
$\mathrm{H}_{2} \mathrm{O}$ (calc.) & 5.62 & - & 5.59 & 4.3 & - & 4.8 \\
$\mathrm{Total}$ & 100.76 & - & 100 & 98.62 & - & 100.00 \\
& & & & & & -
\end{tabular}

* calculated for $\mathrm{Pb}_{1.00}\left(\mathrm{Co}_{1.00} \mathrm{Ni}_{0.65} \mathrm{Zn}_{0.35}\right)_{\Sigma 2.00}\left(\mathrm{AsO}_{4}\right)_{2.00}\left(\mathrm{H}_{2} \mathrm{O}\right)_{2.00}$

calculated for $\left(\mathrm{Pb}_{0.96} \mathrm{Ca}_{0.04}\right)_{\Sigma 1.00}\left(\mathrm{Zn}_{0.89} \mathrm{Cu}_{0.50} \mathrm{Fe}_{0.58}^{3+} \mathrm{Al}_{0.03}\right)_{\Sigma 2.00}\left[\left(\mathrm{AsO}_{4}\right)_{1.99}\left(\mathrm{SO}_{4}\right)_{0.01}\right]_{\Sigma 2.00}\left[(\mathrm{OH})_{0.61}\left(\mathrm{H}_{2} \mathrm{O}\right)_{1.39}\right]_{\Sigma 2.00}$

mean of 11 analyses

mean of 16 analyses

gradient of the curve near $x=1.0$ is indefinite, equal ranges for gartrellite and zincgartrellite were assumed (Fig. 1). Samples with $0<x<0.4$ should be assigned to gartrellite, those with $0.4<$ $x<\sim 0.8$ to zincgartrellite. Samples with $x$ close to 1.0 are helmutwinklerite which is separated from zincgartrellite by distinct structural features. It should be mentioned that the experimentally verified substitution of $2 \mathrm{Zn} \rightleftharpoons$ $\mathrm{Fe}+\mathrm{Cu}$ coupled with a substitution $\mathrm{OH} \rightleftharpoons \mathrm{H}_{2} \mathrm{O}$ for charge balance indicates a continuous transition between gartrellite and zincgartrellite. The transition between zincgartrellite towards a pure $\mathrm{Zn}$ end-member is not proved. An interruption of the chemical transition is possible. For samples with practically $2 \mathrm{Zn}$ atoms pfu $(x \sim 1.0)$ a distinct ordering scheme of the hydrogen bonds causes an important change in the crystal structure. Cell metrics and IR spectra are similar for gartrellite and zincgartrellite but they differ fundamentally for helmutwinklerite. Due to the fact that the structural building principles of helmutwinklerite and zincgartrellite are different, these two minerals should not be considered as simple structure variants. Consequently, zincgartrellite is an independent mineral, not isotypic with helmutwinklerite. On the other hand the extensive incorporation of $\mathrm{Zn}$ differentiates zincgartrellite from gartrellite.

\section{IR absorption spectra}

The FT-IR spectra (Fig. 2) were taken on a Nicolet 5PC instrument equipped with a diamond microcell. They are practically identical for rappoldite and helmutwinklerite with distinct absorption bands at $1590 \mathrm{~cm}^{-1}$ (water bending motion). The $\mathrm{OH}$-stretching motion is split into sharp absorption bands at $-3585 \mathrm{~cm}^{-1}$ and $-3535 \mathrm{~cm}^{-1}$ indicating weak hydrogen bonds. The spectrum of zincgartrellite features distinct differences: it shows only a weak absorption band at $1570 \mathrm{~cm}^{-1}$ due to the lower portion of $\mathrm{H}_{2} \mathrm{O}$ molecules, whereas the absorption in the range of $\sim 3550 \mathrm{~cm}^{-1}$ is missing. Instead of this there is a broad absorption ranging from $\sim 3500 \mathrm{~cm}^{-1}$ to $2500 \mathrm{~cm}^{-1}$ with a maximum at $3100 \mathrm{~cm}^{-1}$ indicating strong to very strong hydrogen bonds. Multiple bonds beyond $\sim 1000 \mathrm{~cm}^{-1}$ are from the arsenate groups. The spectrum of zincgartrellite is similar to that of tsumcorite, ferrilotharmeyerite, and gartrellite (Krause et al., 1998a). The different appearence of the IR spectra in the $3550 \mathrm{~cm}^{-1}$ region may serve as an easy method to distinguish between helmutwinklerite and zincgartrellite. Moreover, from the IR spectrum, samples belonging to the helmutwinklerite type can clearly be distinguished from those belonging to the tsumcorite or gartrellite type. 
SYMMETRY OF TSUMCORITE GROUP MINERALS

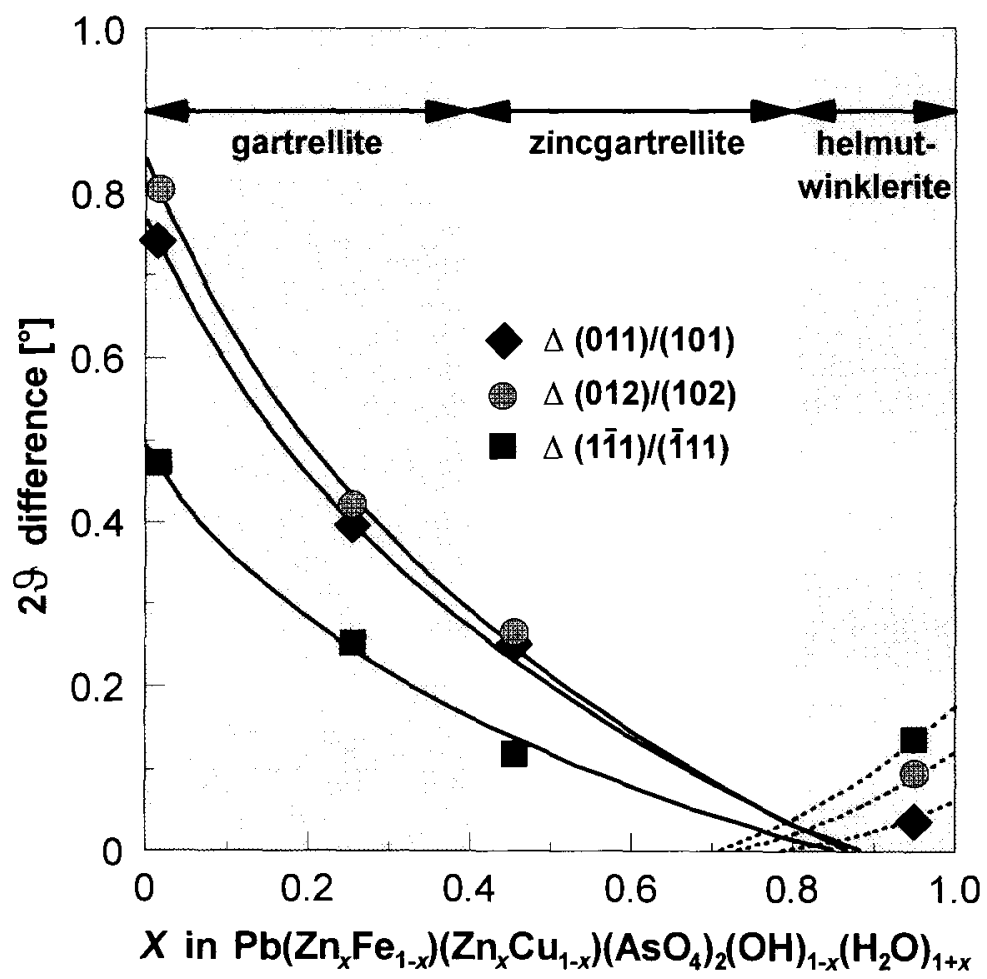

FIG. 1. Triclinic distortion within the gartrellite-zincgartrellite-helmutwinklerite series. The splitting is shown for three selected pairs $29_{h k l}(\mathrm{Cu}-K \alpha$ radiation) for different amounts of $\mathrm{Zn}$ within the relevant sample according to the formula $\mathrm{Pb}\left(\mathrm{Zn}_{x} \mathrm{Fe}_{1-x}\right)\left(\mathrm{Zn}_{x} \mathrm{Cu}_{1-x}\right)\left(\mathrm{AsO}_{4}\right)(\mathrm{OH})_{1-x}\left(\mathrm{H}_{2} \mathrm{O}\right)_{1+x}$.

\section{$\mathbf{X}$-ray investigation}

Powder pattern

The XRD data of the investigated minerals are similar and correspond with the other tsumcorite group minerals. The XRD data of rappoldite are given in Table 3. Indexing is based on the true triclinic supercell. The superstructure reflections were not observed in the powder pattern due to their weak intensities. For the XRD data of zincgartrellite see Krause et al. (1998a; Table $4 b$ 'zincian gartrellite'). Cell parameters derived from the powder data (abstract and Table 4) were confirmed by single-crystal investigations.

\section{Helmutwinklerite and rappoldite}

Helmutwinklerite was first described by Süsse and Schnorrer (1980). Schmetzer et al. (1985) determined a tsumcorite-like pseudocell with $C 2 / m$ symmetry and cell dimensions similar to those of tsumcorite. From additional very weak superstructure reflections these authors deduced a triclinic supercell with a sixteenfold cell volume: $a=4 \times 5.600 \AA=22.400(4) \AA, b=4 \times 5.609 \AA=$ $22.436(4) \AA, c=7.616(3) \AA, \alpha=70.21(2)^{\circ}, \beta=$ $70.02(3)^{\circ}, \gamma=69.24(2)^{\circ}$. These observations were roughly confirmed during investigations by Krause et al. (1998a). However, at least the strongest of the superstructure reflections showed a systematic non-space group extinction for the $h k l$ reflections $(h=2 n+1$ or $k=2 n+1$ and $h, k=$ $4 n+2)$. At that time it was impossible to decide whether the other superstructure reflections were not observed because the intensities were too weak or whether other structure models have to be applied. The distribution of the intensities gave an approximate $C 2 / m$ symmetry for the pseudocell, whereas the superstructure reflections and the cell metrics showed distinct violation of the Lauesymmetry $2 / m$. A structure model was given for the triclinic pseudocell; the anisotropy of the 


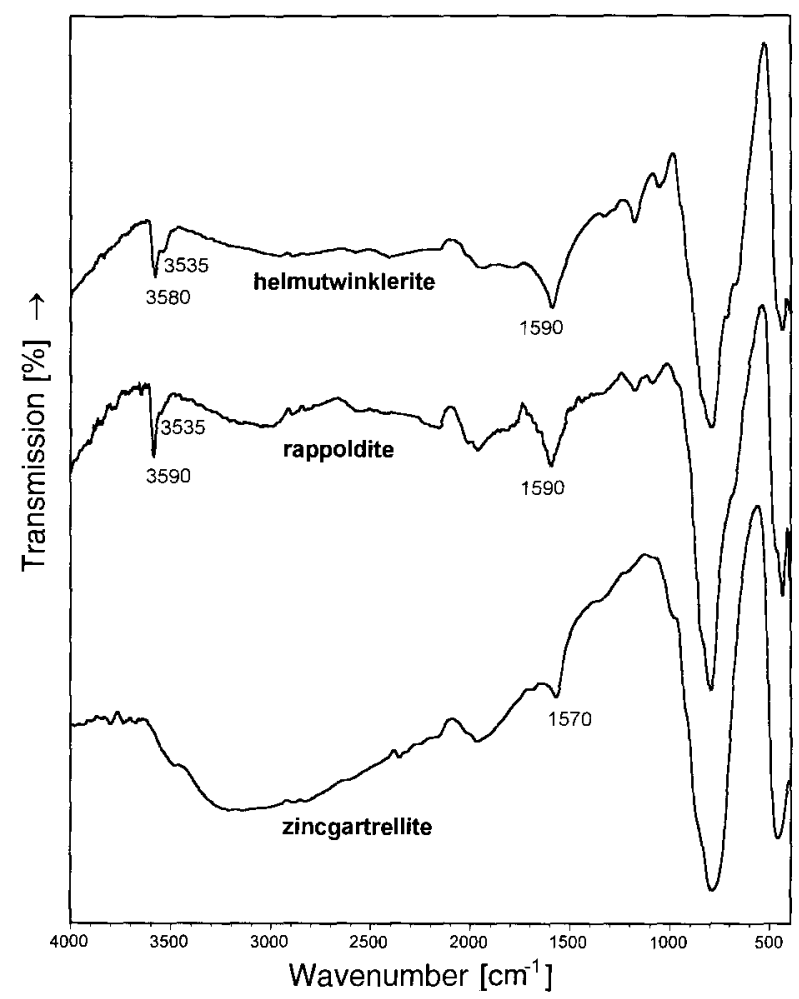

FIG. 2. IR spectra of helmutwinklerite, rappoldite and zincgartrellite.

displacement parameters was large, especially for the atoms $O(1)$ and $O(4)$.

For the present single-crystal X-ray studies, an automatic four-circle diffractometer equipped with a CCD-area detector was used. A few rappoldite crystals and the crystal chip of helmutwinklerite used formerly (Krause et al., $1998 a$ ) were investigated by this new technique. Due to the improved signal-to-noise ratio, information within the reciprocal space was obtained which could not be seen on X-ray film investigations even when the exposure time was very long (Weissenberg and precession technique). The intensity distribution for helmutwinklerite and rappoldite is basically the same, but it differs from all the other investigated tsumcorite group minerals. The strong reflections correspond roughly with a monoclinic $C$-centred cell, characteristic of the tsumcorite type (monoclinic subcell). The additional reflections are weak, but clearly seen. They definitely do not cause fourfold triclinic subcell parameters $a$ and $b$ as described earlier. The distribution of the superstructure reflections is shown schematically in Fig. $3 a$. Indexing is possible based on the assumption of a twinned triclinic supercell with fourfold cell volume as compared to the triclinic subcell. The twin plane $\{2 \overline{3} 0\}$ corresponds to the mirror plane of the space group $\mathrm{C} 2 / \mathrm{m}$ in the average cell, i.e. the twin plane ( $1 \overline{1} 0)$ observed for the gartrellitetype minerals. All investigated samples of rappoldite and helmutwinklerite are twinned. The cell parameters and their transformations are given in Table 4; the relations in the direct space are given in Fig. $3 b$. For convenience throughout this paper, the three principally different cells are referred to as 'tsumcorite type cell' (space group $C 2 / m$, average monoclinic subcell, $Z=2$ ), 'gartrellite-type cell' (space group $P \overline{1}$, average triclinic subcell, $Z=1$ ) and 'helmutwinklerite-type cell' (space group $P \overline{1}$, true triclinic supercell, $Z=4$ ).

The intensity of the superstructure reflections is weak. In rappoldite the average intensity of the main reflections is 4437 whereas that of the superstructure reflections is only 137. In addi- 
SYMMETRY OF TSUMCORITE GROUP MINERALS

TABLE 3. Powder diffraction data of rappoldite.

\begin{tabular}{|c|c|c|c|c|c|c|c|c|c|}
\hline$h k l$ & $d_{\text {calc }}$ & $I_{\text {calc }}$ & $d_{\mathrm{obs}}$ & $I_{\mathrm{obs}}$ & $h k l$ & $d_{\text {calc }}$ & $I_{\text {calc }}$ & $d_{\mathrm{obs}}$ & $I_{\mathrm{obs}}$ \\
\hline 001 & 6.926 & 19 & 6.920 & 22 & $42 \overline{3}$ & 2.017 & 9 & 2.017 & 10 \\
\hline $2 \overline{1} 0$ & 5.072 & 31 & & & $2 \overline{1} 3$ & 1.931 & 14 & & \\
\hline 020 & 5.045 & $4\}$ & 5.056 & 3 & 023 & 1.925 & 14 & 1.925 & 13 \\
\hline$\overline{2} 11$ & 4.673 & $\left.\begin{array}{l}75 \\
81\end{array}\right\}$ & 4.670 & 97 & $21 \overline{4}$ & 1.898 & 11 & 1.898 & 10 \\
\hline $0 \overline{2} 1$ & 4.670 & & & & $2 \overline{3} 3$ & 1.870 & 11 & 1.870 & 8 \\
\hline $21 \overline{1}$ & 4.493 & 43 & 4.490 & 26 & $\overline{2} 33$ & 1.863 & 11 & & \\
\hline 210 & 4.192 & 25 & 4.192 & 14 & $\overline{6} \quad 1 \quad 1$ & 1.857 & 4 & 1.863 & 8 \\
\hline $2 \overline{1} 1$ & 3.685 & $5\}$ & 3672 & 3 & $2 \overline{5} 2$ & 1.849 & 13 & & \\
\hline 021 & 3.665 & $5\}$ & $3.6 / 2$ & 3 & $25 \overline{1}$ & 1.848 & 5 & 1.846 & 12 \\
\hline 002 & 3.462 & $13\}$ & 3462 & 26 & $\overline{4} 42$ & 1.846 & 12 & 1.040 & 12 \\
\hline $21 \overline{2}$ & 3.453 & $6\}$ & 3.402 & 20 & $4 \overline{2} 2$ & 1.843 & 7 & & \\
\hline 022 & 3.260 & 74 & 3256 & 100 & 042 & 1.833 & 8 & 1.833 & 6 \\
\hline$\overline{2} 12$ & 3.255 & $74\}$ & 3.256 & 100 & 421 & 1.811 & 3 & & \\
\hline $2 \overline{3} 0$ & 3.172 & 39 & 3.170 & 29 & 402 & 1.768 & 3 & 1.763 & 3 \\
\hline 211 & 3.072 & 100 & 3.072 & 56 & 232 & 1.762 & 3 & & \\
\hline $2 \overline{3} 1$ & 2.888 & 45 & & & $\overline{6} 31$ & 1.744 & 14 & & \\
\hline$\overline{2} 31$ & 2.879 & $44\}$ & 2.890 & 40 & 213 & 1.743 & 3 & 1.744 & 8 \\
\hline 401 & 2.763 & 45 & & & $61 \overline{1}$ & 1.741 & 9 & & \\
\hline 231 & 2.754 & 45 & 2.760 & 37 & $0 \overline{6} 1$ & 1.737 & 14 & & \\
\hline$\overline{4} 21$ & 2.595 & 3 & & & $44 \overline{1}$ & 1.736 & 9 & 731 & 38 \\
\hline $0 \overline{4} 1$ & 2.587 & 3 & 2.581 & 25 & $\begin{array}{lll}0 & 0 & 4\end{array}$ & 1.732 & 23 & 1.731 & \\
\hline $2 \overline{1} 2$ & 2.581 & 30 & & & $42 \overline{4}$ & 1.727 & 19 & & \\
\hline 022 & 2.571 & 32 & & & $\overline{6} 13$ & 1.703 & 28 & 1.700 & 21 \\
\hline$\overline{4} 02$ & 2.570 & 26 & & & $25 \overline{3}$ & 1.700 & 29 & & \\
\hline $23 \overline{2}$ & 2.566 & 25 & 2.568 & 46 & $4 \overline{4} 2$ & 1.696 & 7 & 1.696 & 14 \\
\hline 400 & 2.563 & 10 & & & $\overline{6} 32$ & 1.691 & 6 & & \\
\hline 230 & 2.552 & 11 & & & $6 \overline{3} 0$ & 1.691 & 4 & & \\
\hline $4 \overline{2} 0$ & 2.536 & 22 & 2.537 & 14 & $\overline{2} 52$ & 1.687 & 7 & 1.687 & 8 \\
\hline 040 & 2.522 & 21 & 2.521 & 16 & $0 \overline{6} 2$ & 1.687 & 6 & & \\
\hline $21 \overline{3}$ & 2.501 & 21 & 2.502 & 25 & 060 & 1.682 & 5 & & \\
\hline$\overline{4} 22$ & 2.337 & $17\}$ & & & $4 \overline{4} 4$ & 1.630 & 14 & & \\
\hline 042 & 2.335 & $18\}$ & 2.335 & 27 & $\overline{4} 24$ & 1.627 & 15 & & \\
\hline $42 \overline{2}$ & 2.247 & 11 & 2.245 & 5 & 610 & 1.623 & 6 & 1.626 & 11 \\
\hline $4 \overline{2} 1$ & 2.213 & 16 & 2.212 & 6 & 440 & 1.619 & 6 & & \\
\hline $04 \mathrm{l}$ & 2.200 & 15 & 2.199 & 7 & $2 \overline{5} 3$ & 1.618 & 3 & & \\
\hline 420 & 2.096 & 15 & 2.096 & 7 & $4 \overline{6} 0$ & 1.586 & 27 & 1.585 & 7 \\
\hline$\overline{4} 41$ & 2.022 & 91 & & 9 & $6 \overline{\mathrm{I}} \mathrm{l}$ & 1.577 & 17 & 1.577 & 5 \\
\hline $2 \overline{5} 1$ & 2.021 & $10\}$ & 2.022 & 9 & 251 & 1.569 & 18 & 1.569 & 5 \\
\hline
\end{tabular}

Philips powder diffractometer PW1710, Cu-K $\alpha$ radiation, external standard: Si; texture effects not considered. Calculations were performed using the program LAZY PULVERIX (Yvon et al., 1977) according to the results of structure refinements; reflections with $I_{\text {calc }} \geqslant 3$ are listed; indexing accords with the triclinic supercell.

tion, faint streaks are observed. Their intensity is $\sim 2-3$ times greater than the background intensity. The superstructure reflections are located along these streaks. It is assumed that the streaks are caused by disorder phenomena connected with the hydrogen bonds even in the triclinic supercell. Structural changes were considered possible at low temperatures.
Therefore an additional data set was collected for rappoldite at $T=100 \mathrm{~K}$. The ratio of intensities between the substructure reflections, superstructure reflections and streaks is maintained qualitatively in the temperature interval between $100 \mathrm{~K}$ and $293 \mathrm{~K}$. Therefore, the refined structural parameters are nearly the same for both measurements. 
a

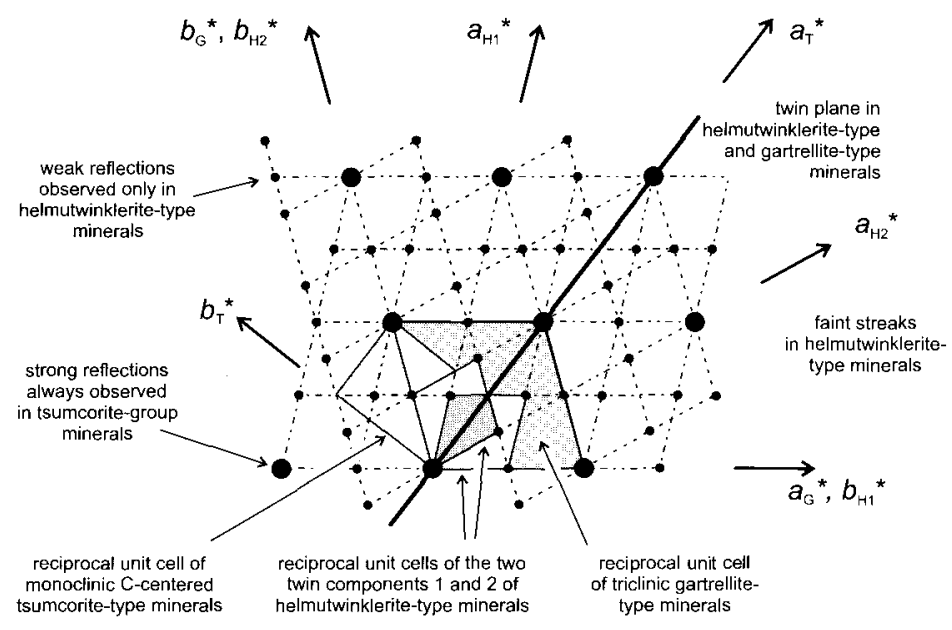

b

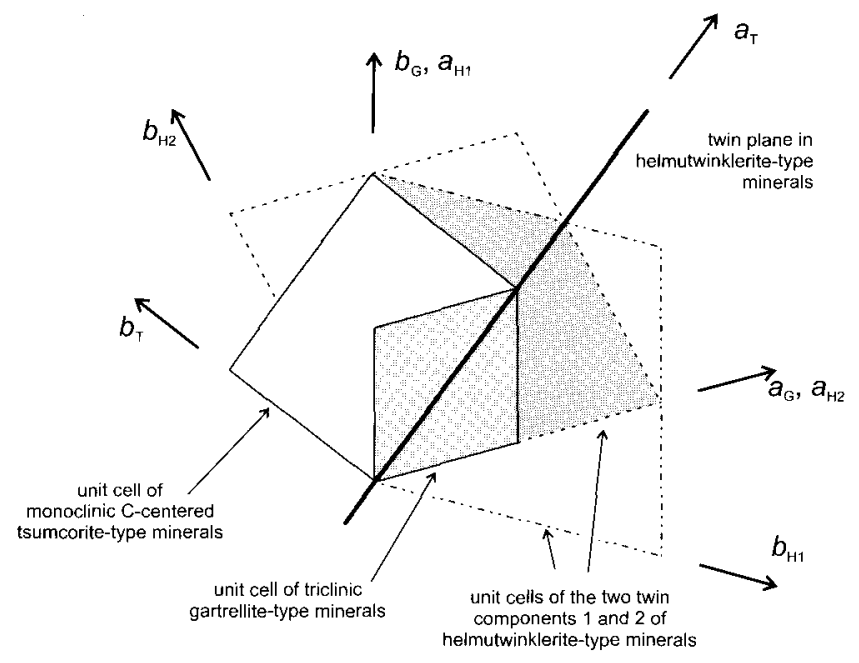

Fig. 3. (a) Relations between the reciprocal unit cells of tsumcorite group minerals: (i) the monoclinic $C$-centred tsumcorite type $\left(a_{\mathrm{T}}{ }^{*}, b_{\mathrm{T}}{ }^{*}\right)$; (ii) the triclinic gartrellite type $\left(a_{\mathrm{G}}{ }^{*}, b_{\mathrm{G}}{ }^{*}\right)$; and (iii) the two twin components observed for the helmutwinklerite type $\left(a_{\mathrm{H} 1}{ }^{*}, b_{\mathrm{H} 1}{ }^{*}\right.$ and $\left.a_{\mathrm{H} 2}{ }^{*}, b_{\mathrm{H} 2}{ }^{*}\right)$. (b) Relations between the unit cells of tsumcorite group minerals: (i) the monoclinic $C$-centred tsumcorite type $\left(a_{\mathrm{T}}, b_{\mathrm{T}}\right)$; (ii) the triclinic gartrellite type $\left(a_{\mathrm{G}}, b_{\mathrm{G}}\right)$; and (iii) the two twin components observed for the helmutwinklerite type $\left(a_{\mathrm{H} 1}, b_{\mathrm{H} 1}\right.$ and $\left.a_{\mathrm{H} 2}, b_{\mathrm{H} 2}\right)$.

Structure models of helmutwinklerite and rappoldite were refined in the true triclinic supercell, the average triclinic and average monoclinic subcells starting from the atomic parameters of tsumcorite (Tillmanns and Gebert, 1973) after appropriate transformations. The differences of the results of refinements (atomic coordinates, anisotropic displacement parameters and residuals) in the triclinic and the monoclinic average subcells are similar. In both models, large anisotropies of the displacement parameters of the atoms $\mathrm{O}(1)$ and $\mathrm{O}(4)$ were found. The displacements of the $\mathrm{Pb}, M e(2)$ and $\mathrm{As}$ atoms are inconspicuous, and of the other atoms, moderate. 
TABLE 4. Cell parameters for rappoldite, helmutwinklerite, and zincgartrellite. Data are refined from the powder diffraction patterns. The cell parameters of helmutwinklerite are from Krause et al. (1998a). The transformation matrices for rappoldite and helmutwinklerite are from the triclinic supercell to the triclinic average subcell $(1 / 200 / 1 / 41 / 20 / 00 \overline{1})$ and from the triclinic supercell to the monoclinic average subcell $(3 / 41 / 20 /-1 / 41 / 20 / 001)$.

\begin{tabular}{|c|c|c|c|c|c|c|c|c|}
\hline & \multicolumn{3}{|c|}{ Rappoldite } & \multicolumn{3}{|c|}{ Helmutwinklerite } & \multicolumn{2}{|c|}{ Zincgartrellite } \\
\hline & \multicolumn{2}{|c|}{$\begin{array}{c}\text { Space group } \\
P \overline{1}\end{array}$} & \multirow{2}{*}{$\begin{array}{c}\text { Space group } \\
C 2 / m \\
\text { subcell }\end{array}$} & \multicolumn{2}{|c|}{$\begin{array}{c}\text { Space group } \\
P \overline{1}\end{array}$} & \multirow{2}{*}{$\begin{array}{c}\text { Space group } \\
C 2 / m \\
\text { subcell }\end{array}$} & \multirow{2}{*}{$\begin{array}{c}\text { Space group } \\
P \overline{\mathrm{l}} \\
\text { true cell }\end{array}$} & \multirow{2}{*}{$\begin{array}{c}\text { Space group } \\
C 2 / m \\
\text { average cell }\end{array}$} \\
\hline & supercell & subcell & & supercell & subcell & & & \\
\hline$a[\AA]$ & $11.190(2)$ & $5.595(1)$ & $9.190(2)$ & $11.220(4)$ & $5.606(2)$ & $9.233(4)$ & $5.550(1)$ & $9.177(2)$ \\
\hline$b[\AA]$ & $10.548(2)$ & $5.572(1)$ & $6.343(1)$ & $10.605(4)$ & $5.610(2)$ & $6.367(3)$ & $5.620(1)$ & $6.368(2)$ \\
\hline$c[\AA]$ & $7.593(1)$ & $7.593(1)$ & $7.593(1)$ & $7.617(1)$ & $7.617(1)$ & $7.617(1)$ & $7.621(1)$ & $7.621(1)$ \\
\hline$\alpha\left[{ }^{\circ}\right]$ & $100.38(1)$ & $70.19(1)$ & $90.11(1) \rightarrow 90$ & $100.60(2)$ & $70.19(2)$ & $90.22(2) \rightarrow 90$ & $68.59(1)$ & $89.30(1) \rightarrow 90$ \\
\hline$\beta\left[^{\circ}\right]$ & $109.59(2)$ & $70.41(1)$ & $114.18(1)$ & $109.81(2)$ & $69.91(2)$ & $114.49(2)$ & $69.17(1)$ & $116.01(1)$ \\
\hline$\gamma\left[{ }^{\circ}\right]$ & $98.96(1)$ & $69.23(1)$ & $90.25(1) \rightarrow 90$ & $98.81(2)$ & $69.18(2)$ & $90.04(2) \rightarrow 90$ & $69.51(1)$ & $90.77(1) \rightarrow 90$ \\
\hline$V\left[\AA^{3}\right]$ & 807.6 & 201.9 & 403.8 & 814.8 & 203.7 & 407.4 & 200.1 & 400.2 \\
\hline$Z$ & 4 & 1 & 2 & 4 & 1 & 2 & I & 2 \\
\hline
\end{tabular}




\section{H. EFFENBERGER ETAL.}

The superstructure reflections and the diffuse streaks therefore result predominantly from order and disorder phenomena of the displacements of the atoms $O(1)$ and $O(4)$ and from the arrangement of the $\mathrm{H}$ atoms. Multiple refinement models in the triclinic supercell were tried (with and without constraints for atoms which are symmetrically equivalent in the average cells and which show low anisotropic displacement parameters) without success. The large correlation terms observed during the refinements in the true cell of rappoldite and helmutwinklerite did not allow a successful refinement. In addition, the distinct streaks observed for all investigated samples indicate strong disorder phenomena. This part of $\mathrm{X}$-ray scattering was not introduced to the refinement model; it is considered that the streaks contribute to the unsuccessful refinement in the true cell. Due to the significant triclinic cell metrics, the structural parameters are given for the average triclinic subcell.

\section{Thometzekite}

The ideal formula of thometzekite is $\mathrm{Pb}(\mathrm{Cu}, \mathrm{Zn})_{2}\left(\mathrm{AsO}_{4}\right)_{2} \cdot 2 \mathrm{H}_{2} \mathrm{O}$ (Schmetzer et al., 1985). Consequently, its crystal structure is expected to be close to that of helmutwinklerite and rappoldite. Several crystals, taken from part of the type material (by courtesy of L. Krahn), were investigated using the automatic four-circle diffractometer equipped with a $\mathrm{CCD}$ area detector. Even frames examined using long exposure times showed neither superstructure reflections nor streaks. The cell metrics gave no hint of a triclinic distortion. This is obviously related to the significant sulphate contents of the crystals available for investigation; according to electron microprobe analyses 9 to $34 \mathrm{~mol} . \%$ of $\mathrm{AsO}_{4}$ are substituted by $\mathrm{SO}_{4}$. In contrast, Schmetzer et al. (1985) mentioned no sulphate in the original description of thometzekite. Due to the fact that $M e(1)$ and $M e(2)$ are solely occupied by divalent cations, the incorporation of $\mathrm{SO}_{4}$ results in an increased $\mathrm{OH}$ content; the average $\mathrm{OH} / \mathrm{H}_{2} \mathrm{O}$ ratio in the investigated samples is $0.75: 1.25$. The distinct $\mathrm{OH}$ content of 'sulphatian thometzekite' obviously prevents an ordering of the hydrogen bonds for the $\mathrm{H}_{2} \mathrm{O}$ molecules and leads to the normal $\mathrm{H}_{3} \mathrm{O}_{2}$ dominant H-bonding system (Krause et al., 1998a). Therefore 'sulphatian thometzekite' is monoclinic and belongs to the tsumcorite type with space group $\mathrm{C} 2 / \mathrm{m}$.
According to various electron microprobe and $\mathrm{X}$-ray powder analyses, the investigated thometzekite samples seem to contain at least two, possibly three phases: (1) sulphatian thometzekite, monoclinic, as proved by structure investigations (Krause et al., 1998a); (2) almost sulphatefree thometzekite with significant $\mathrm{Fe}^{3+}$ and $\mathrm{Al}^{3+}$, probably designated to the gartrellite type; and (3) presumably in very small amounts thometzekite in the strict sense, $\mathrm{Pb}(\mathrm{Cu}, \mathrm{Zn})_{2}\left(\mathrm{AsO}_{4}\right)_{2} \cdot 2 \mathrm{H}_{2} \mathrm{O}$. Only the sulphatian thometzekite could be isolated as a pure sample for single-crystal X-ray studies. Most powder patterns of thometzekite including the powder data given by Schmetzer et al. (1985) can be interpreted as a mixture of sulphatian thometzekite [cell parameters: $a=9.088(2), b=6.311(1), c=$ $\left.7.656(2) \AA, \beta=116.76(2)^{\circ}\right]$ and gartrellite-type thometzekite [cell parameters: $a=5.464(2), b=$ 5.677(2), $c=7.623(4) \AA, \alpha=67.85(3), \beta=$ 69.61(3), $\left.\gamma=69.72(3)^{\circ}\right]$.

It seems likely that 'sulphate-free thometzekite' is structurally related to helmutwinklerite and rappoldite and shows triclinic symmetry with the large unit cell containing four formula units. These considerations are supported by the fact that the displacement parameters observed for the $\mathrm{O}$ atoms in thometzekite are larger than those observed for the $\mathrm{O}$ atoms in the other tsumcoritetype minerals. Due to lack of suitable material, no investigations on pure thometzekite to prove these hypothetical symmetry relations, have been performed.

\section{Zincgartrellite}

Zincgartrellite is isostructural with gartrellite, but closely related to helmutwinklerite chemically. The deviation from monoclinic symmetry is small, though triclinic symmetry is evident from powder pattern, cell metrics, intensity distribution of single-crystal X-ray data, and structure investigation. Superstructure reflections or diffuse streaks (by analogy with helmutwinklerite and rappoldite) were not seen. The crystal structure was refined starting from the atomic parameters of gartrellite (Krause et al., 1998a). During the final least-squares refinements, anisotropic displacement parameters were allowed to vary for the $M e$ and $X$ atoms but isotropic ones for the oxygen atoms. The scattering functions of the position $\operatorname{Me}(2 \mathrm{a})=(\mathrm{Zn}, \mathrm{Fe})$ were successfully refined. Due to the similar scattering power of $\mathrm{Zn}$ and $\mathrm{Cu}$, the ratios $\mathrm{Zn}: \mathrm{Cu}$ at the $M e(2 \mathrm{~b})$ 


\section{SYMMETRY OF TSUMCORITE GROUP MINERALS}

position was kept equal to $\mathrm{Zn}: \mathrm{Fe}$ at the $M e(2 \mathrm{a})$ position according to the structural formula $\mathrm{Pb}\left(\mathrm{Zn}_{x} \mathrm{Fe}_{1-x}\right)\left(\mathrm{Zn}_{x} \mathrm{Cu}_{1-x}\right)\left(\mathrm{AsO}_{4}\right)(\mathrm{OH})_{1-x}\left(\mathrm{H}_{2} \mathrm{O}\right)_{1+x}$. The coordination polyhedra $M e(2 a)^{[6]} \mathrm{O}_{6}$ and $\mathrm{Me}(2 \mathrm{~b})^{[4+2]} \mathrm{O}_{6}$ are clearly different. The refined value $\mathrm{Fe}: \mathrm{Zn}=\mathrm{Cu}: \mathrm{Zn}$ is $0.4(2): 0.6(2)$ which is in reasonable agreement with the results of the electron-microprobe investigation. The cell parameters are included in Table 4.

\section{Structure refinement}

The data collection was performed using a Nonius four-circle diffractometer (Mo tube, graphite monochromator) equipped with a CCD detector with a frame size of $621 \times 576$ pixels (binned mode). The detector-to-sample distance was $28 \mathrm{~mm}$. Data were collected in the $\phi$-scan mode (total rotation $360^{\circ}$, scan speed: $0.1 \% \mathrm{~min} ; \Delta \phi=$ $2 \%$ frame). Corrections for Lorentz and polarization effects were applied in the usual way. Further details of data collection and structure refinements of rappoldite and zincgartrellite are given in Table 5. For the structure refinements neutralatomic complex scattering functions (Wilson, 1992) and the programs SHELX-76 and SHELXL-97 (Sheldrick, 1976, 1997) were used. Structural parameters are given in Table 6 and interatomic bond distances and bond angles in Table 7.

\section{Discussion}

\section{The $\mathrm{Me}(l)$ position}

The $M e(1)$ position shows a pronounced [6+2]coordination to $\mathrm{O}$ atoms. The average $<\mathrm{Me}(1)^{[6]}-\mathrm{O}>$ distance of rappoldite $(2.597 \AA)$ and zincgartrellite $(2.59 \AA)$ is within the range of the other tsumcorite group minerals containing $\mathrm{Pb}$ $(2.584-2.620 \AA)$. The two additional ligands are at $\sim 3.0 \AA$. Only in thometzekite [8]-coordination with an average $\left\langle M e(1)^{[8]}-\mathrm{O}\right\rangle$ distance of $2.688 \AA$ was observed.

\section{The $\mathrm{Me}(2)$ position}

In the tsumcorite group minerals described earlier, the $M e(2)$ position is predominantly occupied by $\mathrm{Fe}^{3+}, \mathrm{Zn}$ and $\mathrm{Cu}$ atoms; the only exception was $\mathrm{Mn}^{3+}$ in lotharmeyerite. Recently it became evident that other elements like $\mathrm{Co}$ and $\mathrm{Ni}$ can be incorporated (Krause et al., 1999b). The position $M e(2)$ in space group $C 2 / m$ is split in the triclinic structure models. In the average triclinic subcell of rappoldite the two $M e(2)$ positions are approximately half occupied by $\mathrm{Co}$ atoms; $\mathrm{Ni}$ and $\mathrm{Zn}$ are additional main constituents; $\mathrm{Fe}^{3+}$ is subordinate. During refinement, the site occupation of $\operatorname{Me}(2 \mathrm{a})$ and $\operatorname{Me}(2 \mathrm{~b})$ in rappoldite was fixed to the analytically determined value for $\mathrm{Ni}$ and $\mathrm{Fe}$. The $\mathrm{Co}: \mathrm{Zn}$ ratio was

TABLE 5. Details of X-ray data collection and structure refinement of rappoldite (structure model for the triclinic subcell, space group $P \overline{1})$ and of zincgartrellite.

\begin{tabular}{lll}
\hline & Rappoldite & Zincgartrellite \\
\hline Crystal dimensions $[\mu \mathrm{m}]$ & $42 \times 67 \times 340$ & $15 \times 55 \times 60$ \\
$\mu(\mathrm{Mo}-K \alpha)\left[\mathrm{mm}^{-1}\right]$ & 32 & 34 \\
Range of data collection & $30<29<50^{\circ}$ & $3^{\circ}<29<45^{\circ}$ \\
Total measured reflections & 754 & 801 \\
$R_{\text {int }}=\Sigma \mid F_{\mathrm{o}}^{2}-F_{\mathrm{o}}^{2}($ mean $) / \Sigma F_{\mathrm{o}}^{2}$ & 0.082 & 0.54 \\
Unique reflections $(\mathrm{n})$ & 664 & 552 \\
Observed reflections with $\mathrm{F}_{\mathrm{o}}>4 \sigma\left(F_{\mathrm{o}}\right)$ & 658 & 238 \\
Variable parameters $(p)$ & 76 & 49 \\
Max $\Delta / \sigma$ & $\leqslant 0.001$ & $\leqslant 0.00 \mathrm{~L}$ \\
GooF $=\left\{\Sigma\left[w\left(F_{\mathrm{o}}^{2}-F_{\mathrm{c}}^{2}\right)^{2} 2\right] /(n-p)\right\}^{0.5}$ & 1.17 & 1.13 \\
$w R 2=\left[\Sigma w\left(F_{\mathrm{o}}^{2}-F_{\mathrm{c}}^{2}\right)^{2} / \Sigma w F_{\mathrm{o}}^{4}\right]^{1 / 2}$ & 0.135 & 0.203 \\
$R=\left[\Sigma\left\|\left|F_{\mathrm{o}}\right|-\left|F_{\mathrm{c}} \| / \Sigma\right| F_{\mathrm{o}}\right]\right](\mathrm{observed}$ data) & 0.047 & 0.081 \\
$w=1 /\left[\sigma^{2}\left(F_{\mathrm{o}}^{2}\right)+\left(a^{*} \mathrm{P}\right)^{2}+b^{*} \mathrm{P}\right], \mathrm{P}=\left(\left[\max \left(0, F_{\mathrm{o}}^{2}\right)\right]+2^{*} F_{\mathrm{c}}^{2}\right) / 3$ & $a=0.0916, b=1.81$ & $a=0.1367, b=12.88$ \\
Extinction coefficient & $0.025(52)$ & not refined \\
Final difference Fourier map (near Pb atoms) $\left[\mathrm{eA}^{-3}\right]$ & -2.60 to +2.80 & -1.95 to +1.63 \\
& & \\
\hline
\end{tabular}


TABLE 6. Structural parameters for rappoldite and zinkgartrellite, with average triclinic subcell, space group $P \bar{l}$. The anisotropic displacement parameters are defined as: $\exp \left[-2 \pi^{2} \sum_{i=1}^{3} \Sigma_{j=1}^{3} U_{\mathrm{ij}} \mathbf{a}_{i}^{*} \mathbf{a}_{j}^{*} h_{i} h_{j}\right], U_{\text {cquiv }}$ according to Fischer and Tillmanns (1988).

\begin{tabular}{|c|c|c|c|c|c|c|c|c|c|}
\hline atom & $x$ & \multicolumn{2}{|c|}{$y$} & $z$ & $U_{\text {equiv }} / U_{\text {iso }}$ & & & & \\
\hline \multicolumn{10}{|l|}{ Rappoldite } \\
\hline$M e(1)=\mathrm{Pb}$ & 0 & \multicolumn{2}{|l|}{$\begin{array}{l}0 \\
0.5\end{array}$} & 0 & $0.0340(5)$ & & & & \\
\hline$M e(2 \mathrm{a})=(\mathrm{Co}, \mathrm{Ni}, \mathrm{Zn})$ & 0 & 0.5 & & 0.5 & $0.0210(9)$ & & & & \\
\hline$M e(2 b)=(\mathrm{Co}, \mathrm{Ni}, \mathrm{Zn})$ & 0.5 & \multicolumn{2}{|l|}{0} & 0.5 & $0.0201(9)$ & & & & \\
\hline$X=$ As & $0.4241(3)$ & \multicolumn{2}{|c|}{$0.4220(2)$} & $0.7751(2)$ & $0.0203(7)$ & & & & \\
\hline$O(1)$ & $0.1575(19)$ & \multicolumn{2}{|c|}{$0.1556(18)$} & $0.4045(17)$ & $0.033(2)$ & & & & \\
\hline $\mathrm{O}(2)$ & $0.3119(17)$ & \multicolumn{2}{|c|}{$\begin{array}{l}0.3126(15) \\
0.6843(17)\end{array}$} & $0.6446(13)$ & $0.023(2)$ & & & & \\
\hline$O(3 a)$ & $0.2472(19)$ & 0.68 & 17) & $0.2611(14)$ & $0.030(2)$ & & & & \\
\hline$O(3 b)$ & $0.6820(18)$ & \multicolumn{2}{|c|}{$0.2456(16)$} & $0.2608(13)$ & $0.027(2)$ & & & & \\
\hline$O(4)$ & $0.2838(27)$ & \multicolumn{2}{|c|}{$0.2803(27)$} & $0.0056(14)$ & $0.054(3)$ & & & & \\
\hline \multicolumn{10}{|l|}{ Zincgartrellite } \\
\hline$M e(1)=\mathrm{Pb}$ & 0 & \multicolumn{2}{|l|}{0} & 0 & $0.0479(17)$ & & & & \\
\hline$M e(2 \mathrm{a})=(\mathrm{Zn}, \mathrm{Fe})$ & 0 & \multicolumn{2}{|l|}{0.5} & 0.5 & $0.040(5)$ & & & & \\
\hline$M e(2 \mathrm{~b})=(\mathrm{Zn}, \mathrm{Cu})$ & 0.5 & \multirow{2}{*}{\multicolumn{2}{|c|}{$\begin{array}{l}0 \\
0.4266(12)\end{array}$}} & 0.5 & $0.034(3)$ & & & & \\
\hline$X=$ As & $0.4125(9)$ & & & $0.7853(7)$ & $0.032(2)$ & & & & \\
\hline$O(1)$ & $0.163(6)$ & \multicolumn{2}{|c|}{$0.166(8)$} & $0.420(5)$ & $0.034(9)$ & & & & \\
\hline$O(2)$ & $0.306(7)$ & \multicolumn{2}{|c|}{$0.321(9)$} & $0.648(6)$ & $0.052(12)$ & & & & \\
\hline$O(3 a)$ & $0.255(7)$ & \multicolumn{2}{|c|}{$\begin{array}{l}0.679(9) \\
0.238(9)\end{array}$} & $0.258(5)$ & $0.044(10)$ & & & & \\
\hline$O(3 b)$ & $0.691(8)$ & 0.23 & & $0.251(6)$ & $0.049(10)$ & & & & \\
\hline$O(4)$ & $0.273(6)$ & \multicolumn{2}{|c|}{$0.289(8)$} & $0.020(5)$ & $0.037(9)$ & & & & \\
\hline Atom & $U_{11}$ & $U_{22}$ & $U_{33}$ & $U_{23}$ & $U_{13}$ & $U_{12}$ & & $\begin{array}{l}\text { al mean } \\
\text { cements }\end{array}$ & $\begin{array}{l}\text { lare } \\
U\end{array}$ \\
\hline Rappoldite & & & & & & & & & \\
\hline$M e(1)=\mathrm{Pb}$ & $0.0426(7)$ & $0.0300(6)$ & $0.0257(6)$ & $-0.0099(4)$ & $-0.0084(4)$ & $-0.0031(4)$ & 0.049 & 0.029 & 0.023 \\
\hline $\operatorname{Me}(2 \mathrm{a})=(\mathrm{Co}, \mathrm{Ni}, \mathrm{Zn})$ & $0.0243(14)$ & $0.0169(12)$ & $0.0245(13)$ & $-0.0112(9)$ & $-0.0089(9)$ & $0.0000(9)$ & 0.031 & 0.021 & 0.012 \\
\hline$M e(2 \mathrm{~b})=(\mathrm{Co}, \mathrm{Ni}, \mathrm{Zn})$ & $0.0210(15)$ & $0.0163(12)$ & $0.0250(13)$ & $-0.0103(9)$ & $-0.0086(9)$ & $0.0004(8)$ & 0.029 & 0.019 & 0.012 \\
\hline$X=$ As & $0.0252(11)$ & $0.0184(9)$ & $0.0230(10)$ & $-0.0100(6)$ & $-0.0087(6)$ & $-0.0050(6)$ & 0.028 & 0.022 & 0.011 \\
\hline $\mathrm{O}(1)$ & $0.022(6)$ & $0.024(4)$ & $0.065(7)$ & $-0.018(4)$ & $-0.027(5)$ & $0.004(4)$ & 0.068 & 0.021 & 0.011 \\
\hline$O(2)$ & $0.024(5)$ & $0.018(4)$ & $0.035(5)$ & $-0.012(4)$ & $-0.014(4)$ & $-0.004(3)$ & 0.038 & 0.020 & 0.010 \\
\hline$O(3 a)$ & $0.027(6)$ & $0.031(5)$ & $0.040(5)$ & $0.000(4)$ & $-0.019(4)$ & $-0.015(4)$ & 0.051 & 0.027 & 0.013 \\
\hline$O(3 b)$ & $0.031(6)$ & $0.016(4)$ & $0.039(5)$ & $-0.021(4)$ & $0.003(4)$ & $-0.009(4)$ & 0.052 & 0.027 & 0.004 \\
\hline $\begin{array}{l}\mathrm{O}(4) \\
\text { zincgartrellite }\end{array}$ & $0.071(9)$ & $0.079(9)$ & $0.021(5)$ & $-0.010(5)$ & $-0.002(5)$ & $-0.040(7)$ & 0.091 & 0.052 & 0.021 \\
\hline $\operatorname{Me}(1)=\mathrm{Pb}$ & $0.061(2)$ & $0.045(3)$ & $0.033(2)$ & $0.003(2)$ & $-0.020(1)$ & $-0.014(2)$ & 0.063 & 0.056 & 0.025 \\
\hline $\operatorname{Me}(2 \mathrm{a})=(\mathrm{Zn}, \mathrm{Fe})$ & $0.033(6)$ & $0.044(8)$ & $0.029(6)$ & $0.006(5)$ & $-0.009(4)$ & $-0.009(5)$ & 0.066 & 0.033 & 0.022 \\
\hline $\operatorname{Me}(2 \mathrm{~b})=(\mathrm{Zn}, \mathrm{Cu})$ & $0.047(5)$ & $0.026(6)$ & $0.026(4)$ & $0.008(4)$ & $-0.016(4)$ & $-0.016(4)$ & 0.051 & 0.036 & 0.014 \\
\hline$X=\mathrm{As}$ & $0.037(3)$ & $0.034(5)$ & $0.023(3)$ & $0.005(3)$ & $-0.015(2)$ & $-0.010(3)$ & 0.047 & 0.035 & 0.015 \\
\hline
\end{tabular}


TABLE 7. Interatomic bond distances and bond angles for rappoldite (average triclinic subcell) and zincgartrellite.

\begin{tabular}{|c|c|c|c|c|c|}
\hline Bond distances (in $\AA$ ) & Rappoldite & Zincgartrellite & Bond angles $\left({ }^{\circ}\right)$ & Rappoldite & Zincgartrellite \\
\hline$M e(1)-\mathrm{O}(2), 2 \times$ & $3.022(9)$ & $2.96(2)$ & & \multirow{5}{*}{$77.9(3)$ to $102.2(3)$} & \multirow{5}{*}{$75(1)$ to $105(1)$} \\
\hline$M e(1)-\mathrm{O}(3 \mathrm{a}), 2 \times$ & $2.588(9)$ & $2.59(3)$ & \multirow{3}{*}{$\begin{array}{l}\mathrm{O}-M e(1)^{[6]}-\mathrm{O} \\
\text { (neighbouring ligands) }\end{array}$} & & \\
\hline$M e(1)-O(3 b), 2 \times$ & $2.602(8)$ & $2.52(4)$ & & & \\
\hline $\mathrm{Me}(1)-\mathrm{O}(4), 2 \times$ & $2.621(12)$ & $2.65(5)$ & & & \\
\hline $\operatorname{Me}(2 \mathrm{a})-\mathrm{O}(1), 2 \times$ & $2.090(9)$ & $2.00(4)$ & \multirow{3}{*}{$\begin{array}{l}\mathrm{O}-\mathrm{Me}(2 \mathrm{a})-\mathrm{O} \\
\text { (neighbouring ligands) }\end{array}$} & & \\
\hline $\operatorname{Me}(2 \mathrm{a})-\mathrm{O}(2), 2 \times$ & $2.139(9)$ & $2.13(4)$ & & \multirow{2}{*}{$81.4(3)$ to $98.6(3)$} & \multirow[t]{2}{*}{$80(2)$ to $100(2)$} \\
\hline $\operatorname{Me}(2 \mathrm{a})-\mathrm{O}(3 \mathrm{a}), 2 \times$ & $2.074(9)$ & $2.05(4)$ & & & \\
\hline $\operatorname{Me}(2 \mathrm{~b})-\mathrm{O}(1), 2 \times$ & $2.072(9)$ & $1.98(3)$ & \multirow{4}{*}{$\begin{array}{l}\mathrm{O}-\mathrm{Me}(2 \mathrm{~b})-\mathrm{O} \\
\text { (neighbouring ligands) }\end{array}$} & \multirow[t]{4}{*}{$81.4(3)$ to $98.6(3)$} & \multirow[t]{4}{*}{$78(2)$ to $102(2)$} \\
\hline$M e(2 b)-O(2), 2 x$ & $2.154(8)$ & $2.23(5)$ & & & \\
\hline $\operatorname{Me}(2 b)-O(3 b), 2 x$ & $2.063(9)$ & $2.06(4)$ & & & \\
\hline As $-O(2)$ & $1.697(8)$ & $1.71(5)$ & & & \\
\hline$A s-O(3 a)$ & $1.677(10)$ & $1.68(3)$ & \multirow{3}{*}{$\mathrm{O}-\mathrm{As}-\mathrm{O}$} & \multirow{3}{*}{$102.5(5)$ to $112.4(4)$} & \multirow[t]{3}{*}{$106(2)$ to $113(2)$} \\
\hline As $-O(3 b)$ & $1.696(8)$ & $1.71(5)$ & & & \\
\hline As $-O(4)$ & $1.695(10)$ & $1.68(3)$ & & & \\
\hline$O(1) \cdots O(1)$ & $2.64(2)$ & $2.71(8)$ & $O(1) \cdots O(1) \cdots(4)$ & $117.9(6)$ & $108(2)$ \\
\hline$O(1) \cdots O(4)$ & $2.765(15)$ & $2.75(5)$ & $O(1) \cdots O(1) \cdots(3 a)$ & $62.3(4)$ & $57(2)$ \\
\hline$O(1) \cdots O(3 a)$ & $3.020(13)$ & $3.21(7)$ & $O(1) \cdots O(1) \cdots(3 b)$ & $61.5(4)$ & $58(2)$ \\
\hline \multirow[t]{2}{*}{$O(1) \cdots O(3 b)$} & $3.033(13)$ & $3.15(7)$ & $O(4) \cdots O(1) \cdots(3 a)$ & $68.8(4)$ & $66(1)$ \\
\hline & & & $O(4) \cdots O(1) \cdots(3 b)$ & $69.4(4)$ & $64(1)$ \\
\hline
\end{tabular}




\section{H. EFFENBERGER ETAL}

allowed to vary separately for the two positions assuming full occupation. The refined ratio is practically the same for the two sites and is in good agreement with the analytically determined value. According to the differences of the ionic radii (Shannon, 1976), the average $<M e(2 a) /$ $\operatorname{Me}(2 \mathrm{~b})-\mathrm{O}>$ bond distances in rappoldite $(2.101$ and $2.096 \AA$ ) are slightly larger than in the $\mathrm{Fe}^{3+}$ containing compounds (e.g. zincgartrellite: 2.06 and $2.09 \AA$ ), but smaller than in helmutwinklerite $(2.116$ and $2.107 \AA)$. Due to the similarity of geometry, refined occupancy and displacement parameters of the $M e(2 \mathrm{a}) \mathrm{O}_{6}$ and $\mathrm{Me}(2 \mathrm{~b}) \mathrm{O}_{6}$ polyhedron, there is no evidence for ordering on these positions.

As in gartrellite, the triclinic symmetry of zincgartrellite is caused by the different stereochemical requirements of $\mathrm{Fe}$ and $\mathrm{Cu}$. Splitting of $M e(2)$ into two sites, $M e(2 a)$ and $M e(2 b)$, gives the option of adopting different crystal-chemical environments: for $\mathrm{Me}(2 \mathrm{a}) \mathrm{O}_{6}$, the octahedral coordination is maintained; this coordination is favoured by the $\mathrm{Fe}^{3+}$ atoms. The coordination polyhedron $\mathrm{Me}(2 \mathrm{~b}) \mathrm{O}_{6}$ is distorted: the elongated tetragonal bipyramidal $[4+2]$ coordination is favoured by the $\mathrm{Cu}^{2+}$ atoms due to their electron configuration (Jahn-Teller effect). Zinc atoms can substitute for $\mathrm{Fe}^{3+}$ and $\mathrm{Cu}$ and therefore it occupies both of the positions $M e(2 a)$ and $M e(2 b)$. The bonds within the basal square, $M e(2 b)-O(1) / O(3)$, are 2.03/1.91 $\AA$ in gartrellite and 1.98/2.06 $\AA$ in zincgartrellite. The axial bond lengths $M e(2 \mathrm{~b})-\mathrm{O}(2)$ are extended to $2.30 \AA$ in gartrellite and to $2.23 \AA$ in zincgartrellite. The elongation correlates with the different $\mathrm{Cu}$ contents in the two minerals.

\section{Hydrogen bonds}

Most likely from crystal chemical considerations and cogent from structure refinements is the fact that the $\mathrm{H}$-bonding scheme is responsible for the different unit cells and symmetries obtained for rappoldite and helmutwinklerite as compared to the other tsumcorite-group minerals. The chemical formulae for both rappoldite and helmutwinklerite are very close to $\mathrm{Me}(1) \mathrm{Me}(2)_{2}\left(\mathrm{XO}_{4}\right)_{2} \cdot 2 \mathrm{H}_{2} \mathrm{O}$, whereas for the other minerals of this group, a substantial amount of $\mathrm{H}_{2} \mathrm{O}$ is substituted by $\mathrm{OH}$ groups due to charge balance for the different valences of the cations $\operatorname{Me}(1)^{1+, 2+, 3+}, \operatorname{Me}(2)^{2+, 3+}$ and $X^{4+6+}$.

The space group symmetry $C 2 / m$ ('tsumcoritetype cell') and $P \bar{l}$ ('gartrellite type cell') is responsible for symmetrically restricted hydrogen bonds formed between two $\mathrm{OH}$ groups according to

$$
\begin{gathered}
\mathrm{O}(4) \cdots \mathrm{H}(2)-\mathrm{O}(1)-\mathrm{H}(1) \cdots \mathrm{O}(1)-\mathrm{H}(2) \cdots \mathrm{O}(4) \\
\stackrel{\mathrm{O}(4) \cdots \mathrm{H}(2)-\mathrm{O}(1) \cdots \mathrm{H}(1)-\mathrm{O}(1)-\mathrm{H}(2) \cdots \mathrm{O}(4)}{\rightleftharpoons}
\end{gathered}
$$

The $O(1) \cdots O(1)$ distances are very short, the distances $O(1) \cdots O(4)$ are in the usual range for common hydrogen bonds. The angle $O(4)-O(1)-O(1)$ is close to that expected for a water molecule. The ideal formula for this structure type is $\mathrm{Me}(1) \mathrm{Me}(2)_{2}\left(\mathrm{XO}_{4}\right)_{2}(\mathrm{OH})\left(\mathrm{H}_{2} \mathrm{O}\right)$ or even $M e(1) M e(2)_{2}\left(X_{4}\right)_{2}\left(\mathrm{H}_{3} \mathrm{O}_{2}\right)$ (cf. Beran et al., 1997). The hydrogen-bonding scheme is maintained if the symmetry is reduced to $P \overline{1}$ (gartrellite type).

An excess of $\left(\mathrm{H}_{2} \mathrm{O}\right)$ as compared to $(\mathrm{OH})$ causes additional hydrogen bonds. In helmutwinklerite and rappoldite both $O(1)$ atoms form water molecules. The only probable acceptors not involved in an edge of the coordination polyhedra around the $M e$ atoms are two $\mathrm{O}(3)$ atoms. The $O(1) \cdots O(3)$ distances of $\sim 3 \AA$ might enable a bifurcated hydrogen bond. At any rate, the $\overline{1}$ symmetry has to be violated to form two $\mathrm{H}_{2} \mathrm{O}$ molecules (see Fig. 4):

$$
\mathrm{O}(4) \cdots \mathrm{H}(2)-\mathrm{O}(1)-\mathrm{H}(1) \cdots \mathrm{O}\left(\mathrm{l}^{\prime}\right) \text { and }
$$

$$
\stackrel{\mathrm{O}(3)}{\mathrm{O}(3)} \dot{ }^{\mathrm{H}(3)-\mathrm{O}\left(1^{\prime}\right)-\mathrm{H}\left(2^{\prime}\right) \cdots \mathrm{O}(4) .}
$$

The absence of a symmetrically restricted hydrogen bond in rappoldite and helmutwinklerite is indicated by an increase of $O(1) \cdots O(1)$ to $\sim 2.64 \AA$. Even $\mathrm{O}(1) \cdots \mathrm{O}(4)$ is enlarged compared to the other tsumcorite group minerals. Bent hydrogen bonds are assumed from the small angles $\mathrm{O}(3)-\mathrm{O}(1)-\mathrm{O}(4)$ of $\sim 70^{\circ}$ and from the repulsion of the atoms $\mathrm{H}(1)$ and $\mathrm{H}(3)$. The shift of oxygen atoms responsible for these changed features is small. The anisotropic displacement parameters indicate that preferentially the atoms $O(1)$ and $O(4)$ are involved in the rearrangement.

Details of the hydrogen bonding scheme were not derived during the present investigations, but there seems no doubt on the principal ordering mechanism. Within the 'tsumcorite cell' the $M e(1)$ atoms have site symmetry $2 / m$ and the $M e(2)$ atoms are located at inversion centres. In addition, site symmetry $2 / m$ is between each two 




Fig. 4. Hydrogen bonds in the tsumcorite group minerals. The $\mathrm{H}$ atoms characteristic of the $\mathrm{H}_{3} \mathrm{O}_{2}$ group with formal $2 / m$ symmetry (with the split position of the symmetrically restricted hydrogen bond) of the tsumcorite and gartrellite type compounds are shown. The contacts to further $\mathrm{O}(3)$ atoms are indicated. In the helmutwinklerite type, one $\mathrm{H}_{2} \mathrm{O}$ molecule is maintained between $\mathrm{O}(4) \cdots \mathrm{O}(1) \cdots \mathrm{O}(1)$; the other one is between $\mathrm{O}(4) \cdots \mathrm{O}(1) \cdots \mathrm{O}(3)$.

$\mathrm{AsO}_{4}$ tetrahedra and between two $\mathrm{O}(1)$ atoms (average position of the $\mathrm{H}(1)$ atom belonging to the symmetry-restricted hydrogen bond). Within the 'gartrellite cell' all these special positions have site symmetry $\bar{l}$. In helmutwinklerite and rappoldite the absence of the symmetrically restricted hydrogen bond causes a violation of the site symmetry at the average $H(1)$ position. Mechanisms to adapt to these conditions are either a symmetry reduction to $P m$ or $P 1$ or an increase of the cell volume which enables a selective removal of inversion centres. The latter is verified in helmutwinklerite and rappoldite. As shown in Fig. 5, in both twin components of the helmutwinklerite type cells, the symmetry $\bar{l}$ is maintained for parts of the $M e(2)$ atoms and between parts of the $\mathrm{AsO}_{4}$ tetrahedra. For all $M e(1)$ atoms and for the average $H(1)$ positions, the space group causes site symmetry 1 .

\section{Symmetry relations}

In most of the tsumcorite group species the $M e(1)$ position is occupied by divalent cations $(\mathrm{Ca}, \mathrm{Pb})$ and $X$ by pentavalent cations (P,As, $V$ ). The cations occupying the $M e(2)$ site can be divided into three different groups depending on their charge and crystal chemical requirements: (1) divalent cations with a more or less distorted octahedral environment ( $\mathrm{Zn}, \mathrm{Co}, \mathrm{Ni})$; (2) trivalent cations with an octahedral environment $(\mathrm{Fe}, \mathrm{Al})$; and (3) divalent $\mathrm{Cu}$ atoms strictly in a tetragonal 


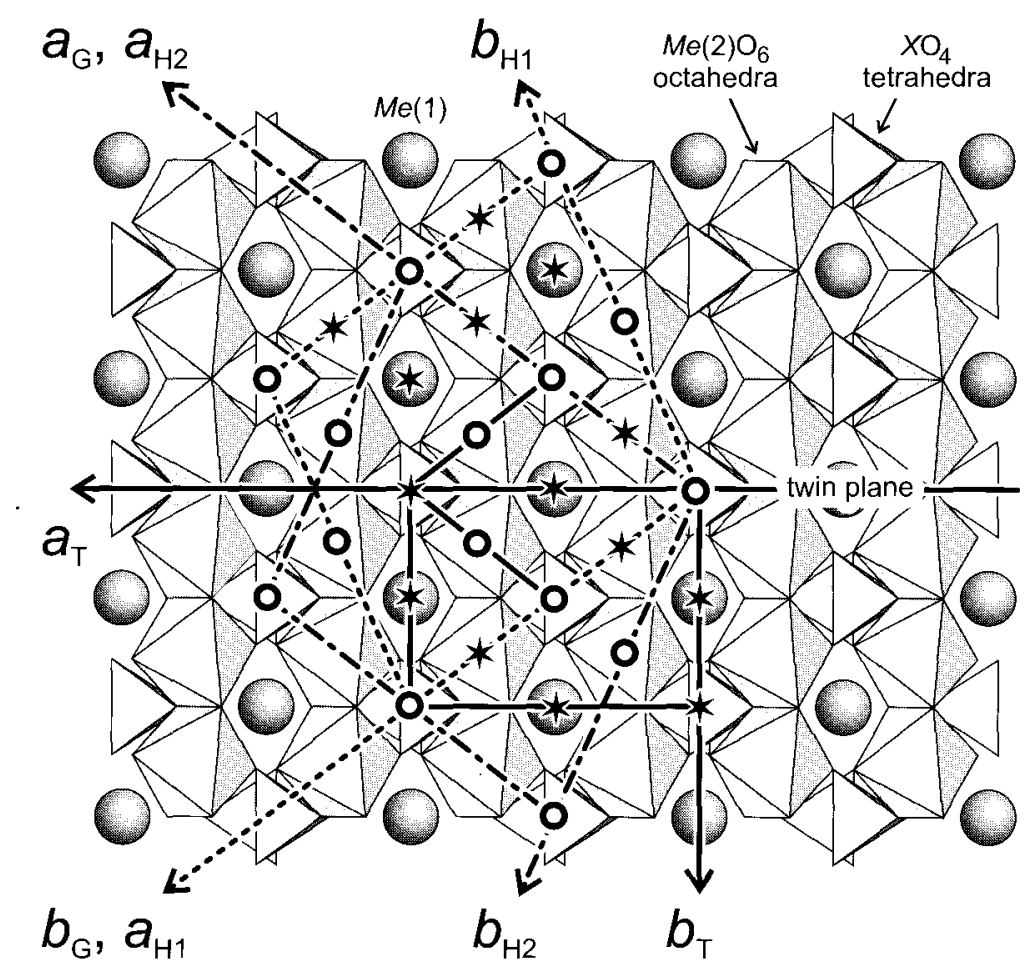

Flg. 5. Structural relations between tsumcorite group minerals: (i) monoclinic $C$-centred tsumcorite type $\left(a_{\mathrm{T}}, b_{\mathrm{T}}\right)$; (ii) triclinic gartrellite type $\left(a_{\mathrm{G}}, b_{\mathrm{G}}\right)$; and (iii) the two twin components observed for the helmutwinklerite type $\left(a_{\mathrm{II}}, b_{\mathrm{H} 11}\right.$ and $a_{\mathrm{H} 2}, b_{\mathrm{H} 2}$ ). The inversion centre in the two twin components of the helmutwinklerite type are indicated by a circle, those verified only in the tsumcorite- and gartrellite type structures are indicated by a star.

dipyramidal environment (distorted octahedron due to the Jahn-Teller effect). For discussion of the crystal symmetries, the tsumcorite group minerals are arranged in a triangle diagram with respect to the cations at the $M e(2)$ position (Fig. 6); the corners are represented by $M e^{2+}$ (excluding $\mathrm{Cu}$ ), $\mathrm{Me}^{3+}$ and $\mathrm{Cu}$.

The tsumcorite group minerals can be divided into three different subgroups characterized by different structure types and related to three different areas in the triangle diagram shown in Fig. 6. This should be regarded only as a model for classifying the different structure types. In particular, the position of the border lines between the areas are assumptions based on the present stage of knowledge and need further verification by additional analyses of natural and/or synthetic samples. This might therefore be subject to changes depending on the results of new investigations.
Area $\mathrm{I}$ is along the $M e^{2+}-M e^{3+}$ edge and represents the tsumcorite type. It is limited by contents of at least $0.2 \mathrm{Me}^{3+}$ atoms pfu and probably no more than $0.2 \mathrm{Cu}$ atoms pfu. Nearly complete solid solution between $M e_{1.8}^{2+} M e_{0.2}^{3+}$ and $\mathrm{Me}_{2}^{3+}$ is taken for granted, based on the crystalchemical properties of the involved cations and on electron microprobe results. A great number of analyses of different species of the tsumcorite group scatter around $M e^{2+}: M e^{3\urcorner} \sim 1: 1$ requiring $\mathrm{OH}: \mathrm{H}_{2} \mathrm{O} \sim 1: 1$ for charge balance. All samples plotted within this area have space-group symmetry $C 2 / m$.

However, the end-members with pure $\operatorname{Me}(2)^{3+}$, i.e. two $\mathrm{OH}$ groups pfu, are still debatable. For mounanaite the probable substitution of $\mathrm{OH}$ groups by $\mathrm{F}$ atoms, but maintaining the spacegroup symmetry $C 2 / m$ was discussed by Krause et al. (1998a). Structural investigations on mawbyite were performed on crystals from the type 


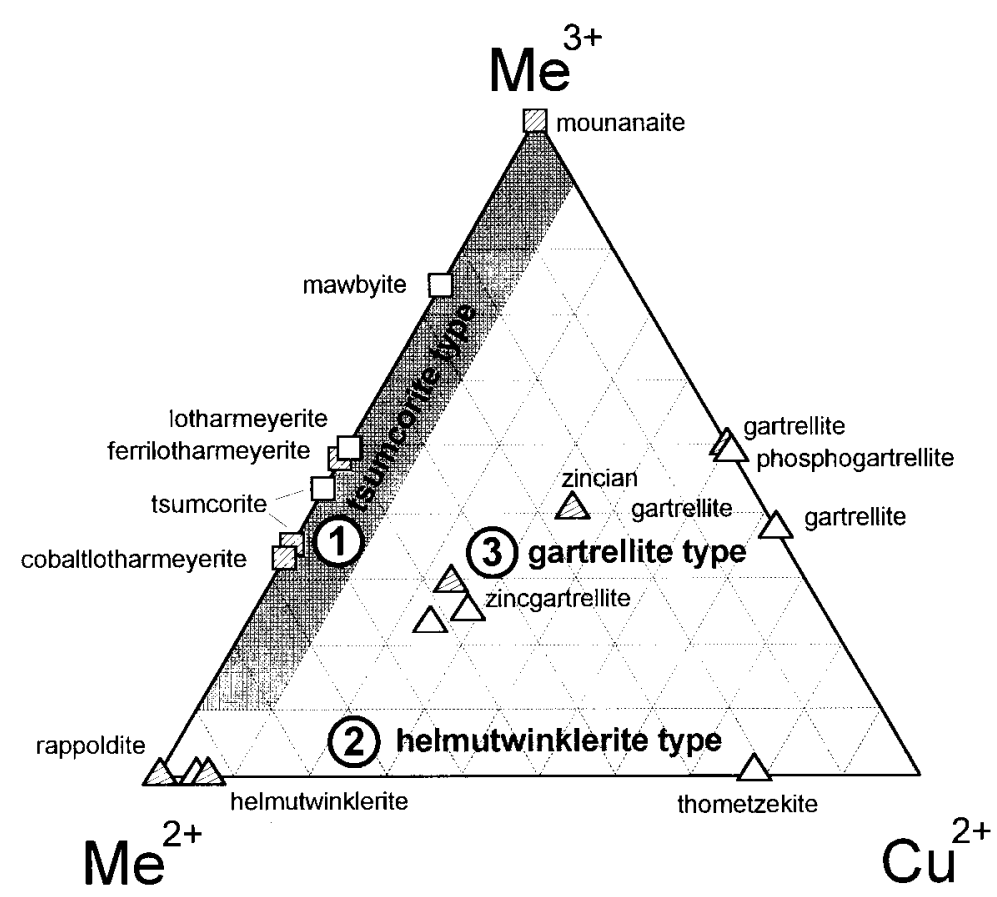

Fici. 6. The chemical composition of the tsumcorite group mincrals with $M e(1)^{2+}$ and $X^{5+}$ atoms plotted in the triangle-diagram $\mathrm{Cu}^{2+}-M e(2)^{2+}$ (other than $\left.\mathrm{Cu}\right)-M e(2)^{3+}$. Type material samples are unfilled, those of structure investigations are hatched. Samples in areas 1,2 and 3 belong to the tsumcorite type $\left(C 2 / m_{1}, Z=2\right)$, helmutwinklerite type $(P \overline{1}, Z=4)$, and gartrellite type $(P \overline{1}, Z=1)$, respectively.

specimen (Kharisun et al., 1997). According to earlier analyses (Pring et al., 1989), the average $\mathrm{OH}: \mathrm{H}_{2} \mathrm{O}$ ratio is $1.47: 0.53$. The tsumcorite type is also verified in a great number of synthetic compounds (references are compiled by Krause et al., 1998a).

Area 2 is along the $M e^{2+}-\mathrm{Cu}$ edge and represents the helmutwinklerite type. Fewer than $\sim 0.2 \mathrm{Me}^{3}$ atoms pfu might be adopted to define the limiting composition. The ideal formula of minerals within this area is $M e(1)^{2} \operatorname{Me}(2)_{2}^{2+}\left(X^{5+} \mathrm{O}_{4}\right)_{2} \cdot 2 \mathrm{H}_{2} \mathrm{O}$. The stability field of the helmutwinklerite type is much less certain than the tsumcorite type of area 1. The only minerals within this area are helmutwinklerite and rappoldite; synthetic compounds are unknown. Pure thometzekite, i.e. $\mathrm{PbCu}_{2}\left(\mathrm{AsO}_{4}\right)_{2} \cdot 2 \mathrm{H}_{2} \mathrm{O}$, and thometzekite with different amounts of $\mathrm{Zn}$ substituting for $\mathrm{Cu}$, should also belong to this group. Nearly complete solid solution can be expected between $\mathrm{Me}^{2+}$ and $\mathrm{Cu}^{21}$. These minerals have triclinic symmetry due to the requirements of four hydrogen bonds pfu.
The unit cell is enlarged and contains four formula units caused by a partial ordering of the hydrogen bonds which avoids symmetryrestricted hydrogen-bonds.

Area 3 represents the gartrellite type and is attributed to minerals with an ordered occupancy of the $M e(2)$ site with cations of distinctly different crystal-chemical behaviour. This refers to $\mathrm{Fe}^{3+}$ and $\mathrm{Cu}^{2+}$ in the examples known so far (gartrellite, zincgartrellite and phosphogartrellite), but an order between other elements might also be possible. The symmetry of the gartrellite type minerals belonging to area 3 is triclinic with $Z=1$. Substantially different $Z_{n}$ contents were found in the gartrellite-zincgartrellite series. According to chemical and structural data, $\mathrm{Zn}$ substitutes for both $\mathrm{Fe}$ and $\mathrm{Cu}$ in nearly equal amounts. The magnitude of the triclinic distortion is controlled by the ratio $(\mathrm{Fe}, \mathrm{Cu}): \mathrm{Zn}$. In the pure $\mathrm{Zn}$ end-member the $M e(2) \mathrm{O}_{6}$, polyhedra are octahedra. In this case the type structure changes to the helmutwinklerite type (area 2). 


\section{H. EFFENBERGER ETAL.}

\section{Acknowledgements}

The authors thank B. Baumgartner and B. Blume for the powder diffraction measurements and $\mathrm{E}$. Jägers for recording FT-IR spectra using a diamond microcell. Samples for investigation were kindly provided by G. Tremmel and L. Krahn.

\section{References}

Beran, A., Giester, G. and Libowitzky, E. (1997) The hydrogen bond system in natrochalcite-type compounds - an FTIR spectroscopic study of the $\mathrm{H}_{3} \mathrm{O}_{2}^{-}$ unit. Mineral. Petrolog., 61, 223-35.

Fischer, R.X. and Tillmanns, E. (1988) The equivalent isotropic displacement factor. Acta Crystallogr., C44, 775-6.

Kharisun, Taylor, M.R., Bevan, D.J.M., Rae, A.D. and Pring, A. (1997) The crystal structure of mawbyite, $\mathrm{PbFe}_{2}\left(\mathrm{AsO}_{4}\right)_{2}(\mathrm{OH})_{2}$. Mineral. Mag., 61, 685-91.

Kharisun, Taylor, M.R., Bevan, D.J.M. and Pring, A (1998) The crystal chemistry of duftite, $\mathrm{PbCuAsO}_{4}(\mathrm{OH})$ and the $\beta$-duftite problem. Mineral. Mag., 62, 121-30.

Krause, W., Belendorff, K., Bernhardt, H.-J., McCammon, C., Effenberger, H. and Mikenda, W. (1998a) Crystal chemistry of the tsumcorite-group minerals. New data on ferrilotharmeyerite, tsumcorite, thometzekite, mounanaite, helmutwinklerite, and a redefinition of gartrellite. Eur. J. Mineral., 10, 179-206.

Krause, W., Belendorff, K., Bernhardt, H.-J. and Petitjean, K. (1998b) Phosphogartrellite, $\mathrm{PbCuFe}\left(\mathrm{PO}_{4}\right)_{2}(\mathrm{OH}) \cdot \mathrm{H}_{2} \mathrm{O}$, a new member of the tsumcorite group. Neues Jahrb. Mineral. Mh., $111-8$.

Krause, W., Bernhardt, H.-J. and Effenberger, H (1999a) Symmetry of tsumcorite-group minerals. Berichte der Deutschen Mineral. Ges., Beih. z. Eur. J. Mineral., 11(1), 136.
Krause, W., Effenberger, H., Bernhardt, H.-J. and Martin, M. (1999b) Cobaltlotharmeyerite, $\mathrm{Ca}(\mathrm{Co}, \mathrm{Fe}, \mathrm{Ni})_{2}\left(\mathrm{AsO}_{4}\right)_{2}\left(\mathrm{OH}, \mathrm{H}_{2} \mathrm{O}\right)_{2}$, a new mineral from Schneeberg, Germany. Neues Jahrb. Mineral. Mh., 505-17.

Martin, M. and Schlegel, F. (1992) Kobaltaustinit und Tsumcorit von der Rappold-Fundgrube in Schneeberg/Sachsen. Lapis, 17, 28-9.

Pring, A., McBriar, E.M. and Birch, W.D. (1989) Mawbyite, a new arsenate of lead and iron related to tsumcorite and carminite, from Broken Hill, New South Wales. Amer. Mineral., 74, 1377-81.

Schmetzer, K., Nuber, B. and Medenbach, O. (1985) Thometzekite, a new mineral from Tsumeb, Namibia, and symmetry relations in the tsumcoritehelmutwinklerite family. Neues Jahrb. Mineral. Mh., $446-52$.

Shannon, R.D. (1976) Revised effective ionic radii and systematic studies of interatomic distances in halides and chalcogenides. Acta Crystallogr., A32, 751-67.

Sheldrick, G.M. (1976) SHELX-76 Programs for Crvstal Structure Determination. Univ. Cambridge, UK.

Sheldrick, G.M. (1997) SHELXL-97 Program for Crystal Structure Refinement. Univ. Göttingen, Germany.

Süsse. P. and Schnorrer, G. (1980) Helmutwinklerite, a new arsenate mineral from Tsumeb, S.W. Africa. Neues Jahrb. Mineral. Mh., 118-24.

Tillmanns, E. and Gebert, W. (1973) The crystal structure of tsumcorite, a new mineral from the Tsumeb Mine, S.W. Africa. Acta Crystallogr.. B29, 2789-94.

Wilson, A.J.C. (editor) (1992) International Tables for Crystallography, Vol. C. Kluwer, Dordrecht, The Netherlands.

Yvon, K.. Jeitschko, W., and Parthé, E. (1977) LAZY PULVERIX, a computer program for calculating $\mathrm{X}$-ray and neutron powder patterns. J. Appl. Crystallogr., 10, 73-4.

[Manuscript received 7 Jamuary 2000. revised 1 September 2000] 